\title{
Modeling market valuation of offshore drilling contractors
}

\author{
Mark J. Kaiser
}

Received: 16 April 2013 /Accepted: 2 March 2014 / Published online: 24 April 2014

(C) World Maritime University 2014

\begin{abstract}
Offshore drilling is big business, and on a worldwide basis, contractor revenues have ranged between $\$ 25$ and 50 billion a year over the past decade. The industry is organized through public, private, and state-owned companies, and in 2012 public companies Seadrill, Transocean, Ensco, Noble, and Diamond dominated the market, followed by mid-market players Rowan, Hercules, and Aban. The industry is competitive and dynamic, and contractor business strategies evolve in response to changing market demands and competitor activity. Contractors derive their cash flow and earnings by leasing rigs for exploration and development and attempt to maximize their revenue through scale economies, specialization, geographic diversity, and safe and efficient operations. The market value of contractors depends upon their rig fleet, contract backlog, and operational and financial characteristics. Market valuations change as supply and demand conditions change and companies upgrade their fleet portfolio and relocate rigs to satisfy demand. The purpose of this paper is to describe the factors that impact contractor value and to develop quantitative models of market valuation for a cross-section of public firms. A high-level overview of the offshore contract market and business strategies of firms is described. Fleet value, contract backlog, revenue, and earnings are significant predictors of market capitalization and enterprise value, and fleet value is the best predictor of firm value.
\end{abstract}

Keywords Offshore drilling contractors $\cdot$ Fleet value $\cdot$ Valuation modeling

\section{Introduction}

Wells are a primary means to produce reserves, and the only way to create a well is to hire a rig and drill. The first offshore wells were drilled from wharfs off the California coast in 1898 (Grosbard 2002). Drilling moved into swamps and coastal transition zones around the world using barge rigs and submersibles, and in 1947, the first well out of sight of land was drilled 9 miles off the coast of Louisiana. Today, drillships are 
capable of drilling 40,000 ft wells in water depth greater than 12,000 ft. In 2012, approximately one third of the world's 85 million barrels of daily oil production was sourced from offshore fields in over 50 countries and on every continent except Antarctica (Serbutoviez 2012).

The offshore drilling industry is composed of five markets (Fig. 1). Mobile offshore drilling units (MODUs or rigs) are owned and operated in the contract drilling market, constructed in the newbuild market, exchanged in the secondhand market, enhanced and maintained in the upgrade market, and complete their lifecycle in the scrap market. Contract drilling is the largest of the five markets and a primary driver of investment decisions throughout the industry. Rig owners lease rigs to exploration and production (E\&P) companies. Cash flow and earnings derive from the use of their fleet of rigs and the dayrates received, utilization, and operational cost in each region of the world in which they operate. Offshore rig chartering is big business with global expenditures over the past decade ranging between $\$ 25$ and 50 billion per year (Fig. 2). Seadrill, Transocean, Ensco, Noble, and Diamond dominate the market and compete with several mid-market players such as Rowan, Hercules, and Aban. Activity is driven by the capital expenditures of E\&P firms which are driven by oil and gas prices, regional and global economic conditions, strategic decisions, and related factors.

The offshore drilling industry is currently composed of approximately 100 publicly owned, privately held, and state-owned firms. Public firms are traded on a stock exchange, private firms restrict share ownership and are not listed on exchanges, and state-owned companies are majority owned by a government entity. Ownership plays a

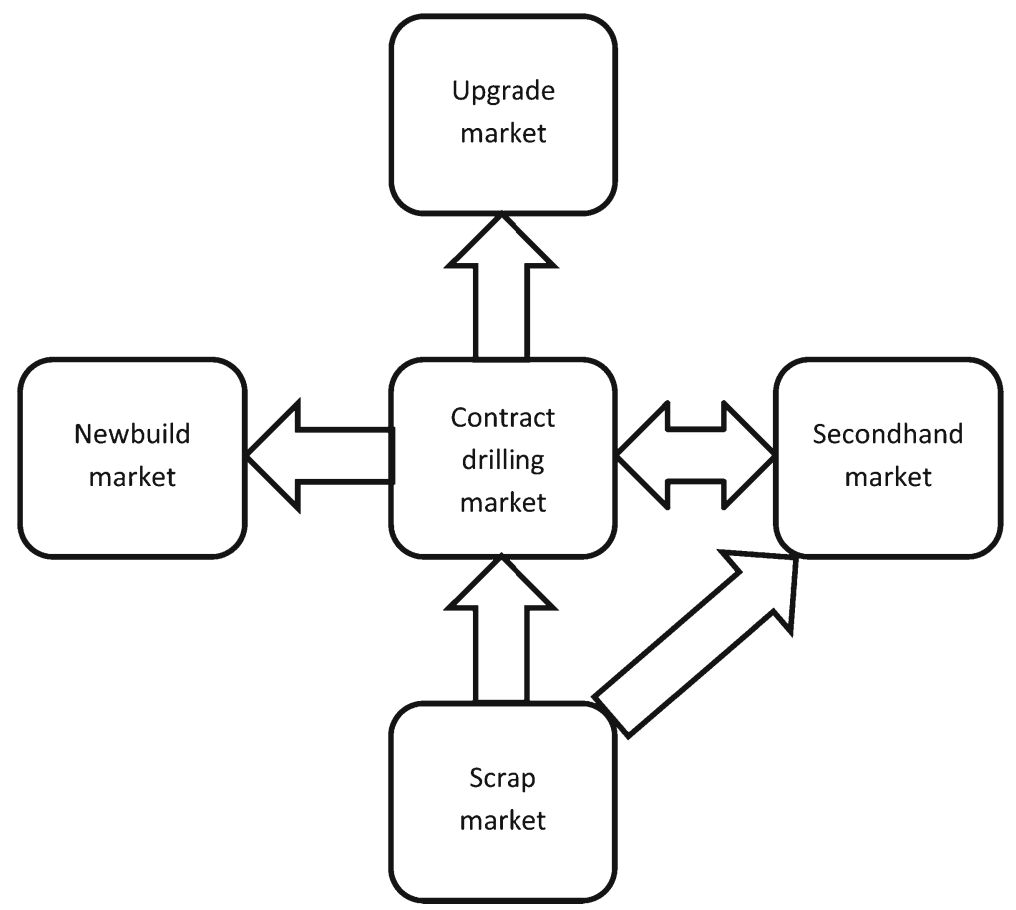

Fig. 1 The five offshore rig markets and the direction of cash flows 


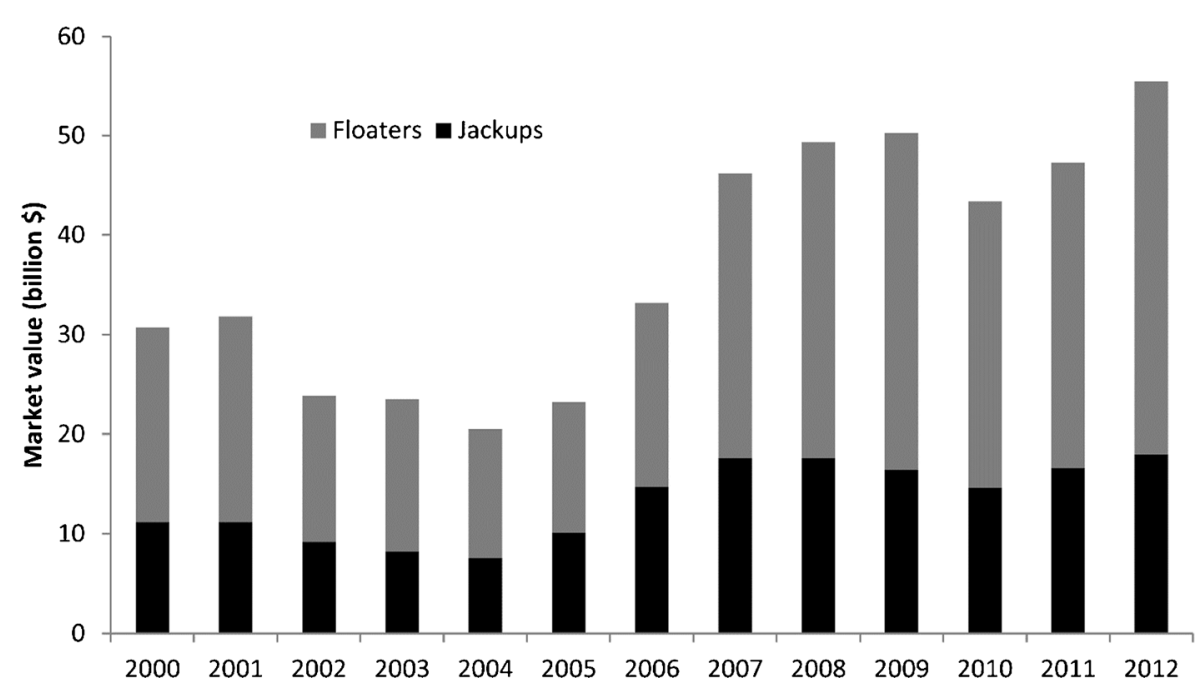

Fig. 2 Offshore contract drilling market revenue, 2000-2012. Source: Data from Riglogix (2011), author calculations

key role in business strategies and strategic goals in the oil and gas industry (Hartley and Medlock 2008; Jablonowski and Kleit 2011). Public companies are responsive to the expectations and demand of their shareholders and are largely concerned with value creation, whereas state-owned firms employ both financial performance and policy goals in their operations. Publicly traded firms are described by their market capitalization and enterprise value. Market capitalization is the total value of tradable shares at a specific point in time, determined by the product of stock price and the number of outstanding shares. Enterprise value is the market capitalization plus debt, minority interest and preferred shares, minus total cash and cash equivalents (Antill and Arnott 2000; Pinto et al. 2010).

The purpose of this paper is to describe the primary factors that impact the value of an offshore drilling contractor and to develop regression models of market capitalization and enterprise value for a cross-section of public contractors. The value of any company is derived from its cash flow and earnings, which are dependent upon the quantity of sales, sales price, and cost structure (Abrams 2010). The market value of a firm reflects the worth of the company and its property on the open market at a specific point in time and is defined as "the estimated amount for which a property should exchange on the date of valuation between a willing buyer and a willing seller in an arms-length transaction after proper marketing wherein both parties had each acted knowledgably, prudently, and without compulsion... reflecting the collective perceptions and actions of a market..." (International Valuation Standards 2005).

The outline of the paper is as follows. We begin with a review of rig types and market dayrates, followed by a summary of market players and their business strategies. There are many factors that impact company value, and we describe and quantify the most important factors, including fleet value and diversity, operating margin, and financial structure. The valuation methodology is outlined and the results of regression models of capitalization and enterprise value are summarized. 
Discussion of the results and limitations of the analysis are presented, and conclusions complete the paper. A cash flow model of net asset value is developed and illustrated in the Appendix.

\section{Rig types}

\subsection{Bottom-supported units}

MODUs are classified as bottom-supported or floating rigs. Bottom-supported rigs are in contact with the seafloor during drilling and include barges and jackups, whereas a floating rig is held in position by anchors or equipped with thrusters using dynamic positioning and include semisubmersibles and drillships.

Bottom-supported units are used for inland and shallow-water regions (Fig. 3). A drilling barge consists of a drilling rig mounted on a barge and are suitable for marsh and coastal water depths less than $30 \mathrm{ft}$. Most offshore contractors do not operate drilling barges and the inland market is considered part of the land market.

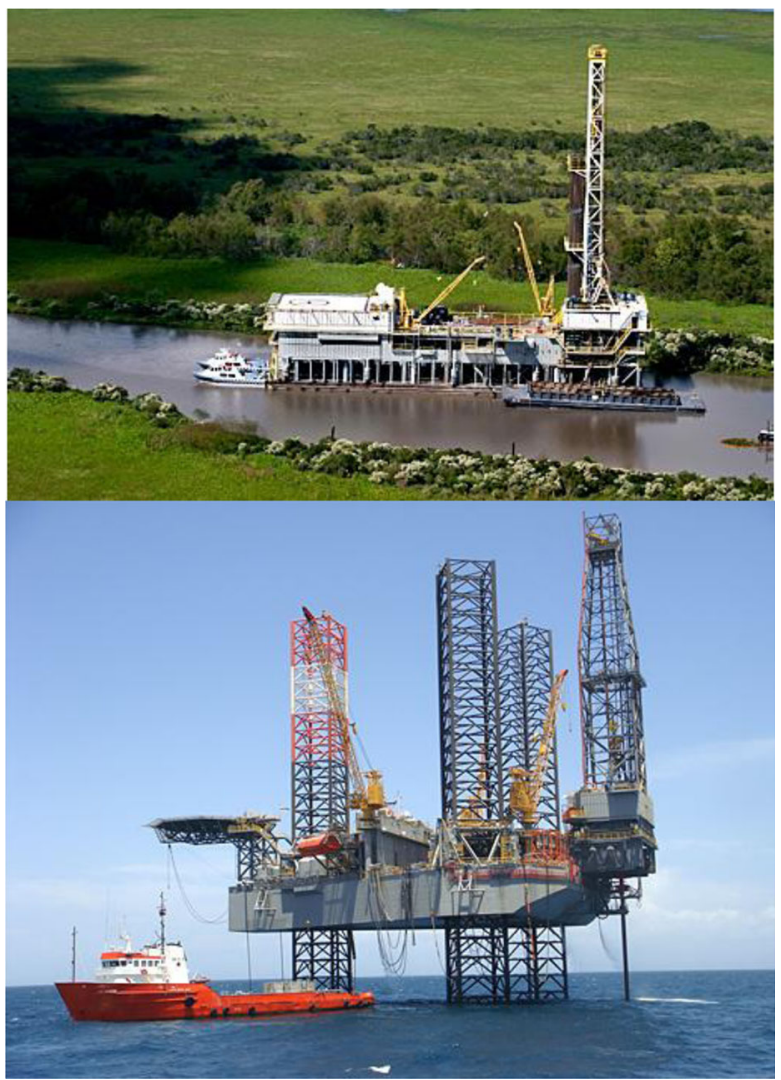

Fig. 3 A drilling barge (top) and a cantilevered jackup drilling rig (bottom). Source: US Department of Energy; Seadrill 
A jackup drilling rig is similar to a drilling barge because the rig is built on a floating hull that is moved to location with tug boats. Once in position, the legs are jacked down to the bottom and after preloading, the hull is jacked above the water level to a height where waves and currents pass below the drilling floor (Vazquez et al. 2005). Jackups operate in open water and are the most common offshore rig in the world capable of drilling on a wide variety of tracks in water depth up to $500 \mathrm{ft}$.

\subsection{Floating units}

Floating units are used for water depth greater than $500 \mathrm{ft}$ (Fig. 4). Semisubmersible drilling rigs are the most common type of floating rig and consist of a deck supported by submerged pontoons connected by several large columns. By varying the amount of ballast in the pontoons, the unit can be raised or lowered to achieve the desired height above the water. The lower the pontoons lie beneath the surface, the less they are affected by wave and current action and the more stable the drilling platform (Halkyard 2005). Semis may be held in place by mooring lines attached to seafloor anchors or by dynamic positioning systems composed of adjustable thrusters.

A drillship is a self-propelled ship-shaped vessel that can mobilize quickly and drill in isolated regions utilizing the storage capacity of its hull. The rig derrick is mounted in the middle of the vessel and drilling is conducted through a large aperture known as a "moon pool." Modern deepwater drillships use dynamic positioning systems to maintain their position. Drillships are the most advanced and expensive sector of the rig market.

\subsection{Specification}

Rigs are classified as high-specification or standard units. A high-specification unit can drill in deeper water than other rigs of its class (typically $>350 \mathrm{ft}$ for jackups and $>7,500 \mathrm{ft}$ for floaters), operate in harsh environments (such as the North Sea, Eastern

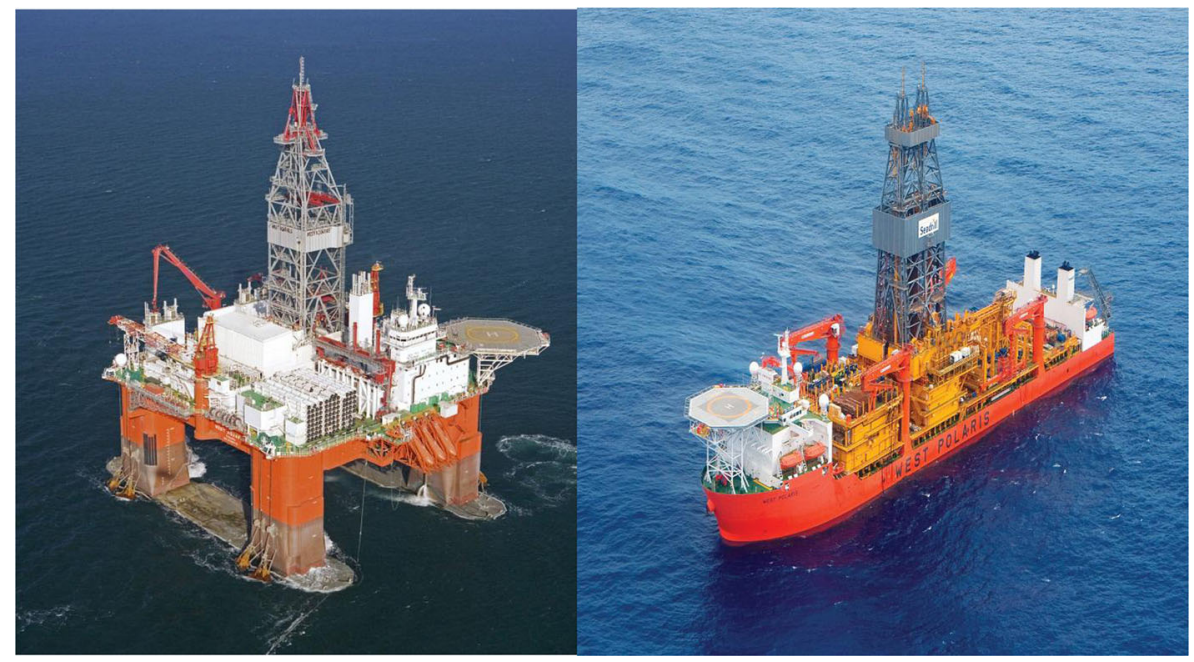

Fig. 4 The West Aquarius semisubmersible and the West Polaris drillship. Source: Seadrill 

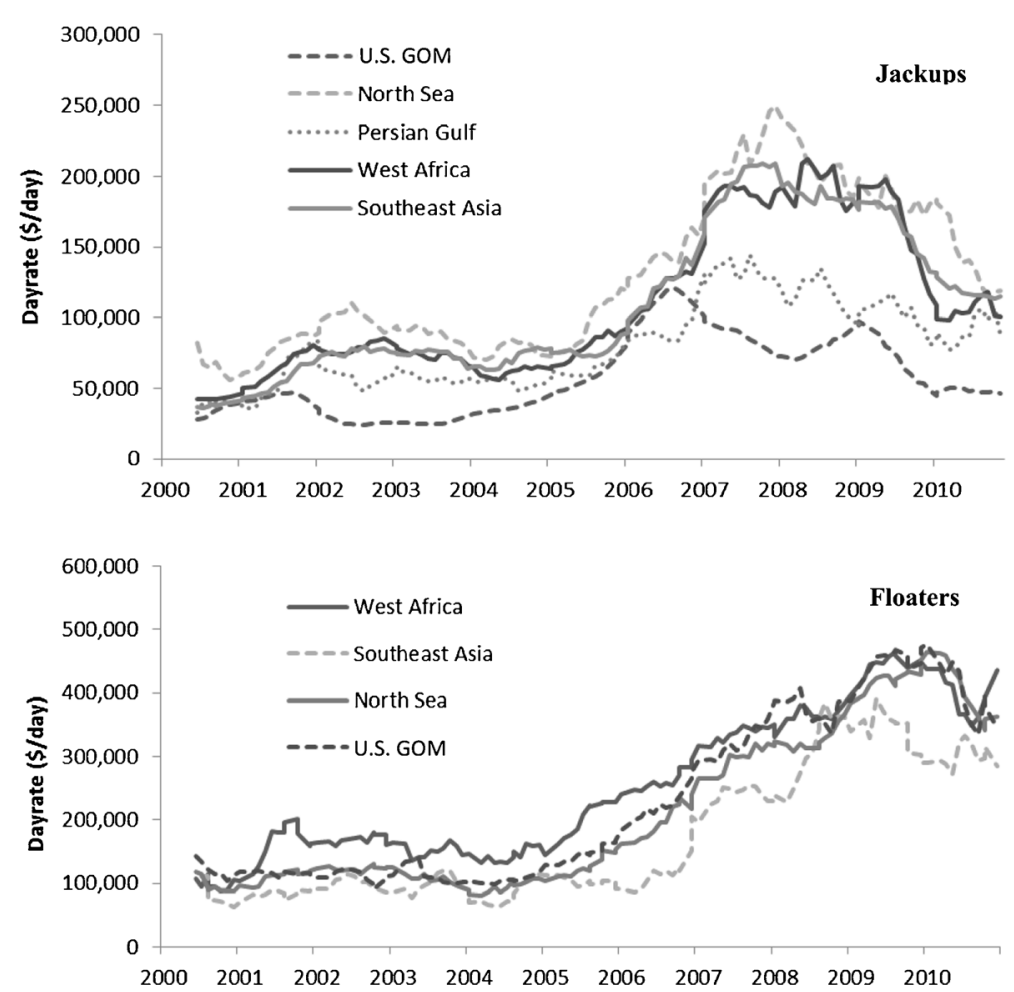

Fig. 5 Regional jackup and floater 6-month average dayrates, 2000-2011. Data from RigLogix (2011)

Canada, or the Arctic), or drill high pressure high temperature wells $(>10,000$ psi or $400^{\circ} \mathrm{F}$ ). High-specification units cost more to build, operate and maintain than standard units, and because of the greater capital expenditures and market demand, they command a dayrate premium over standard rigs.

\section{Dayrates}

Dayrates are the daily price at which contractors release their rigs to E\&P firms ${ }^{1}$ and are a primary descriptor of the market (Fig. 5). Dayrates include the use of the rig and its crew, but do not include most of the other costs associated with drilling a well (e.g., casing, cementing, evaluation, etc.). Supply in the contract drilling market is essentially inelastic in the short run, while demand is highly variable (Carter and Ghiselin 2003). Capacity is added to the fleet through newbuilding, but there are long delays between when rigs are ordered and delivered. Rigs are long-lived assets and are not readily removed from the market, and as a result, there are periods of overcapacity followed by undercapacity and dayrates respond.

\footnotetext{
${ }^{1}$ Additional factors that E\&P companies consider in bid evaluation include the safety record, maintenance programs, reputation, and previous experience with the contractor (Moomjian 1999, 2012; Osmundsen et al. 2008).
} 
Rig demand and dayrates are influenced by a number of market-driven and assetspecific factors (Lawrence and Gabrielsen 1989; McGuire and Gardner 2003; Rankin 1981). Increasing oil prices increase demand for drilling services which lead to increases in dayrates, for all other things equal. When regional utilization is low, the supply of stacked units is large relative to demand and contractors bid aggressively to win work, increasing competition and lowering dayrates. When utilization rates are high, there is more competition among E\&P firms for access to drilling and contractors can negotiate more favorable terms, increasing dayrates and providing signals to the market that additional capacity can be absorbed (Kaiser and Snyder 2013). Contractor business strategies evolve to take advantage of market fluctuations and regional price differences.

\section{Market players}

\subsection{Fleet size}

Transocean had the largest fleet in 2011 at 145 rigs followed by 76 rigs at Ensco and 72 rigs at Noble (Table 1). The top five offshore drillers own rigs in both jackup and floater classes but most other firms specialize to a greater degree. The top four firms own $36 \%$ of rig capacity and the top 20 players constitute $75 \%$ of the total fleet. The remaining fleet is held by about 80 firms, each of which own, on average, approximately three rigs. All but one of the top ten firms are publicly owned.

\subsection{Market value}

Seadrill, Transocean, Ensco, Noble, and Diamond dominated the market in 2011 with revenues over $\$ 2$ billion each and total market capitalization of $\$ 56$ billion. Large-cap firms operate floaters and jackups in multiple geographic regions and all but Seadrill operate both high and low-specification units. All large-cap firms generate almost all of their earnings from offshore drilling. Transocean is the largest offshore drilling contractor in terms of fleet size and revenue, but Seadrill was the largest firm in 2011 in terms of market capitalization and enterprise value.

Mid-market players own eight or more rigs and utilize a broader array of business strategies than large-cap firms, and exhibit greater diversity in terms of fleet size and firm value. Market capitalizations range over an order of magnitude from \$337 million (Vantage) to $\$ 3.7$ billion (Rowan). Mid-market contractors include both publicly traded and state-owned firms, and several players such as Saipem, COSL, Maersk, and Nabors generate a substantial fraction of earnings from other activities.

Firms that own less than eight rigs are regionally specialized and cannot compete successfully in more than one or two markets at a time. Most small players are privately held, but some small firms, especially those that specialize in high-specification floaters, may be publicly traded with large market capitalizations. Ocean Rig and Songa, for example, have market caps greater than $\$ 1$ billion. Unlike mid-market firms, small firms are not major players in large markets but may be important players in small markets, for example, GSP is a major player in the Black Sea and Egyptian Drilling is a major player in the Red Sea. 
Table 1 Fleet size of the largest firms in the offshore contract drilling market in 2011

\begin{tabular}{|c|c|c|c|c|c|c|c|c|}
\hline & Jackups & Semis & Drillships & Total & $\begin{array}{l}\text { Market cap } \\
\text { (million \$) }\end{array}$ & $\begin{array}{l}\text { Enterprise value } \\
\text { (million \$) }\end{array}$ & $\begin{array}{l}\text { Revenue } \\
\text { (million \$) }\end{array}$ & Ownership \\
\hline Transocean & 68 & 52 & 25 & 145 & 13,429 & 23,054 & 9,142 & Public \\
\hline Ensco & 49 & 20 & 7 & 76 & 7,634 & 12,158 & 2,695 & Public \\
\hline Noble & 45 & 14 & 13 & 72 & 11,068 & 15,693 & 2,842 & Public \\
\hline Diamond & 13 & 32 & 3 & 48 & 7,682 & 7,942 & 3,322 & Public \\
\hline Seadrill & 21 & 12 & 6 & 39 & 15,655 & 25,901 & 4,192 & Public \\
\hline Hercules & 53 & 0 & 0 & 53 & 612 & 1,323 & 655 & Public \\
\hline COSL & 27 & 6 & 0 & 33 & 5,810 & 8,960 & 3,050 & Public/state \\
\hline Rowan & 31 & 0 & 0 & 31 & 3,748 & 4,443 & 939 & Public \\
\hline Maersk & 14 & 6 & 0 & 20 & 28,600 & 48,700 & 54,304 & Subsidiary \\
\hline Aban & 15 & 0 & 3 & 18 & 369 & 2,650 & 662 & Public \\
\hline Saipem & 7 & 7 & 2 & 16 & 21,500 & 26,910 & 16,250 & Public \\
\hline Nabors & 16 & 0 & 0 & 16 & 4,344 & 8,642 & 6,060 & Public \\
\hline Atwood & 6 & 6 & 1 & 13 & 2,232 & 2,462 & 645 & Public \\
\hline Ntl. Drilling & 13 & 0 & 0 & 13 & NA & NA & NA & State \\
\hline ONGC & 8 & 0 & 2 & 10 & 4,323 & 5,254 & 21,126 & Public/state \\
\hline Petrobras & 6 & 4 & 0 & 10 & 138,000 & 201,000 & 119,000 & Public/state \\
\hline Socar & 6 & 3 & 0 & 9 & NA & NA & NA & State \\
\hline Fred Olsen & 0 & 7 & 1 & 8 & 2,228 & 2,826 & 1,155 & Public \\
\hline Vantage & 4 & 0 & 4 & 8 & 337 & 1,474 & 485 & Public \\
\hline Stena Drilling & 0 & 4 & 4 & 8 & NA & NA & NA & Private \\
\hline All others & 137 & 50 & 35 & 214 & & & & \\
\hline Total & 539 & 223 & 106 & 868 & & & & \\
\hline
\end{tabular}

Note: Fleet size includes both active and stacked (idle) rigs. Source: Data from RigLogix (2011), Bloomberg

\subsection{Diversification}

Firms are classified according to their degree of diversification across one or more dimensions (Fig. 6). Diversity is usually an indicator of market strength, as it insulates contractors from downturns experienced in specific business segments, and provides upside potential when market conditions improve. A diverse fleet allows contractors to respond to changing industry conditions to match demand trends across geographic region and water depth. Contractors that have a market presence in several regions reduce their political exposure. A firm diversification strategy may change over time, but inventories stabilize changes in the short run.

Generalists maintain a geographically and technically diverse fleet across several regions and water depths with both bottom-supported and floating units. Specialists focus on one rig class or specification and fewer operating regions, and because they tend to be smaller firms with smaller fleets, they cannot simultaneously compete in 

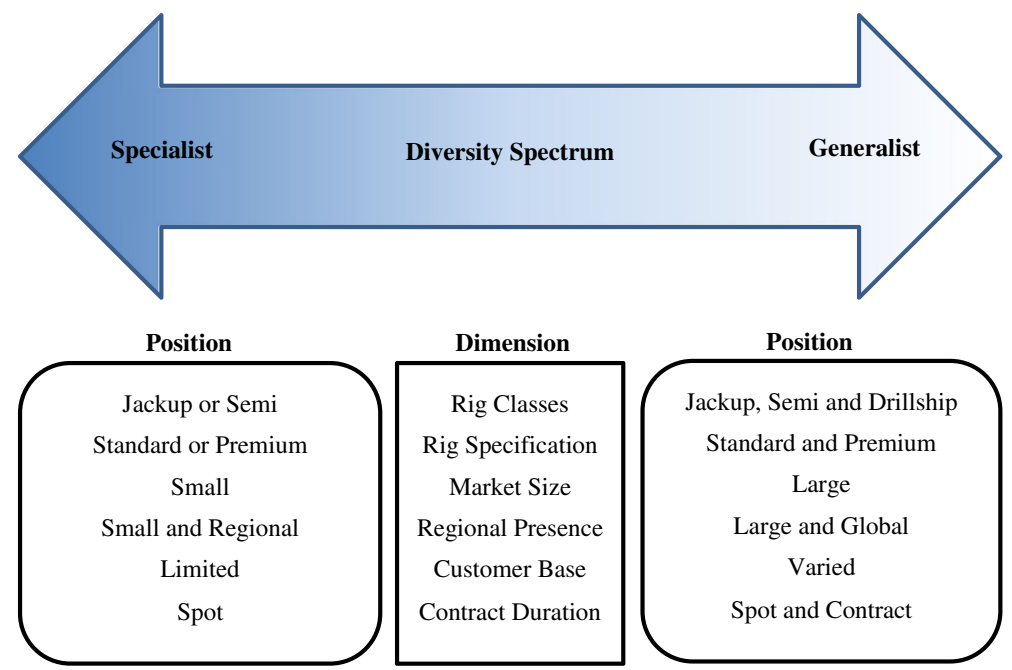

Fig. 6 Characteristics of specialist and generalist offshore drilling contractor firms

more than a few regions and markets. Other dimensions of diversification include customer base and contract portfolio. Generalists tend to have multiple customers and work both short and long-term contracts, but their market position does not necessarily convey a competitive advantage in securing better dayrates (Kaiser and Snyder 2012). Specialists tend to generate a greater percentage of their revenue from fewer customers and operate under either short or long-term contracts.

The five large-cap firms operate significant fleets in both water depth classes. Ensco, Noble, and Transocean are generalists with assets in all rig classes, both the high- and low-specification segments, and across a broad range of geographic markets. Seadrill operates high-specification units across all rig classes and geographic markets. Diamond is a generalist but is focused on regional markets and is not as geographically diverse as Noble, Ensco, and Transocean.

All mid-market firms are active in multiple national markets, but are more regionally specialized than large-cap firms. For example, COSL is focused on the Chinese market, whereas Rowan and Hercules operate primarily in the US Gulf of Mexico and Persian Gulf, Aban in the Indian Ocean, Maersk and Fred Olsen Energy on the North Sea, Nabors and National Drilling in the Persian Gulf, and Saipem in Africa and the Middle East. Atwood and Vantage operate both jackups and floating units, but most other midmarket firms are specialized by class, and Aban, Rowan, and Hercules are jackup specialists, whereas Ocean Rig and Songa are floater specialists.

\subsection{Business strategies}

A company's degree of diversification is usually a good indicator of its business strategy (Table 2). Large-cap firms diversify their risk by operating in a large number of markets and segments. Firms with smaller fleets specialize along at least one dimension and compete in specific market niches. Songa and Fred Olsen, for example, operate mostly harsh-environment semis in the North Sea. Hercules is focused on the standard jackup market in the Gulf of Mexico and Persian Gulf and rarely engages in newbuilding, 
Table 2 Specializations and business strategies of offshore drilling contractors in 2011

\begin{tabular}{|c|c|c|c|c|}
\hline & $\begin{array}{l}\text { Rig } \\
\text { class }\end{array}$ & $\begin{array}{l}\text { Rig } \\
\text { specification }\end{array}$ & $\begin{array}{l}\text { Operating } \\
\text { region }\end{array}$ & Business strategies \\
\hline Diamond & $\begin{array}{l}\text { Jackups and } \\
\text { semis }\end{array}$ & Standard & Global & $\begin{array}{l}\text { Operates an old but upgraded fleet and } \\
\text { is entering high-specification drillship } \\
\text { market }\end{array}$ \\
\hline Ensco & Generalist & Generalist & Global & $\begin{array}{l}\text { Formerly a jackup specialist, but acquired } \\
\text { Pride in 2011, adding floaters } \\
\text { and diversifying fleet }\end{array}$ \\
\hline Fred Olsen & Semis & Generalist & North Sea & $\begin{array}{l}\text { Operates a fleet of mostly older floaters } \\
\text { but includes several harsh units }\end{array}$ \\
\hline Hercules & Jackups & Standard & $\begin{array}{l}\text { GOM/Persian } \\
\quad \text { Gulf }\end{array}$ & $\begin{array}{l}\text { Buys inexpensive secondhand rigs } \\
\text { and usually does not participate } \\
\text { in newbuilding }\end{array}$ \\
\hline Noble & Generalist & Generalist & Global & $\begin{array}{l}\text { Operates a diverse fleet in a number } \\
\text { of regional markets }\end{array}$ \\
\hline Ocean Rig & Floaters & High specification & Global & $\begin{array}{l}\text { Frequently operates in small and emerging } \\
\text { markets (e.g., Ghana, Greenland, } \\
\text { Tanzania, and the Falkland Islands) }\end{array}$ \\
\hline Rowan & Jackups & Generalist & $\begin{array}{l}\text { GOM/Persian } \\
\text { Gulf }\end{array}$ & $\begin{array}{l}\text { Traditional jackup operator moving into } \\
\text { deepwater market; operates primarily } \\
\text { in high-specification shallow water } \\
\text { markets }\end{array}$ \\
\hline Seadrill & Generalist & High specification & Global & $\begin{array}{l}\text { Operates only high-specification rigs; active } \\
\text { in newbuilding and maintains aggressive } \\
\text { growth strategy }\end{array}$ \\
\hline Songa & Semis & High specification & North Sea & Operates small fleet of semis \\
\hline Transocean & Generalist & Generalist & Global & Active in all major regions and water depths \\
\hline Atwood & Generalist & Generalist & Global & $\begin{array}{l}\text { Operates a small but diverse fleet including } \\
\text { floaters and jackups }\end{array}$ \\
\hline
\end{tabular}

Source: Financial reports

whereas Ocean Rig is a high-spec, floating rig specialist that frequently repositions its rigs, often in frontier regions, to take advantage of supply and demand imbalances.

Business strategies evolve and change with changing market conditions to capitalize on opportunities and compete more effectively. In 2011-2012, for example, the jackup specialist Rowan, placed orders for several drillships to enter the floater market; COSL, a Chinese specialist, expanded its geographic base into Africa and the North Sea; and Transocean, a generalist, agreed to sell 38 shallow water drilling rigs to Shelf Drilling International Holdings Ltd for $\$ 1.05$ billion as part of its strategy to unload older rigs and focus on the high end market (Sider 2012).

Several companies operate offshore rigs as a small, noncore part of their business operations. Saipem, Maersk Drilling, Nabors, Petrobras, and Oil and Natural Gas Corporation (ONGC) of India generate less than half of their revenue from offshore drilling. Saipem derives the majority of its revenue from offshore construction, Maersk Drilling is a subsidiary of the shipping conglomerate A.P. Moeller Maersk, Nabors is primarily an onshore drilling contractor, and Petrobras and ONGC are national oil companies. Other firms such as Aban, Fred Olsen Energy, COSL, and Hercules also 
have investments in other industries. Aban has investments in wind energy, Fred Olsen Energy in offshore construction, COSL is an integrated offshore oilfield services company, and Hercules operates a liftboat division.

\section{Factors that impact company value}

\subsection{Fleet size}

Rigs are the primary assets of drilling contractors and fleet inventories are tracked by a number of commercial organizations. Private and state-owned firms usually report their fleet size on company Web pages. The scale and quality of a contractor's fleet is correlated with its revenue base. A large asset base implies a platform for sustainable earnings and cash flows and is related to a company's market position, cost structure, and ability to obtain financing for capital projects.

\subsection{Fleet value}

The net asset value (NAV) of a rig is an estimate of the rig's discounted expected future net earnings evaluated using cash flow models and rig-specific parameters. Fleet value is the sum of the NAV of all the rigs in a firm's fleet. Jefferies, Standard and Poors, ODSPetrodata, and other investment and market intelligence firms develop NAV estimates based on proprietary cash flow models and their data is widely referenced in the industry (Slorer et al. 2011; Glickman 2006), but because economic evaluation is universal, NAVs are easy to compute (See Appendix A). Fleet value is correlated with fleet size because of the commodity-like nature of the rigs and the algorithmic manner in which fleet values are assessed (Fig. 7). Fleet value is expected to be a better predictor of firm value than fleet size because it incorporates variation associated with rig class, specifications, dayrates and contract status, while fleet size only measures the number of rigs.

\subsection{Revenue}

Firm revenue is a function of fleet size, dayrates and utilization rates. Firms with greater revenues will have greater earnings and value, and for all else equal, firms with more valuable fleets are expected to generate greater revenue. Revenue may vary considerably from year to year depending on market conditions and fleet portfolio, and as a result, revenue tends to be a less stable measure than fleet value.

\subsection{Fleet age}

Old fleets are less valuable than new fleets because older rigs receive lower dayrates and utilization, and have fewer remaining years to generate earnings. To illustrate the relation, rigs in the 2010 world fleet were grouped into old (pre-1986 construction) and new (post-1986) ${ }^{2}$ classes and the average dayrates each rig received during the year

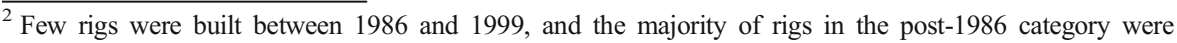
delivered after 2000
} 


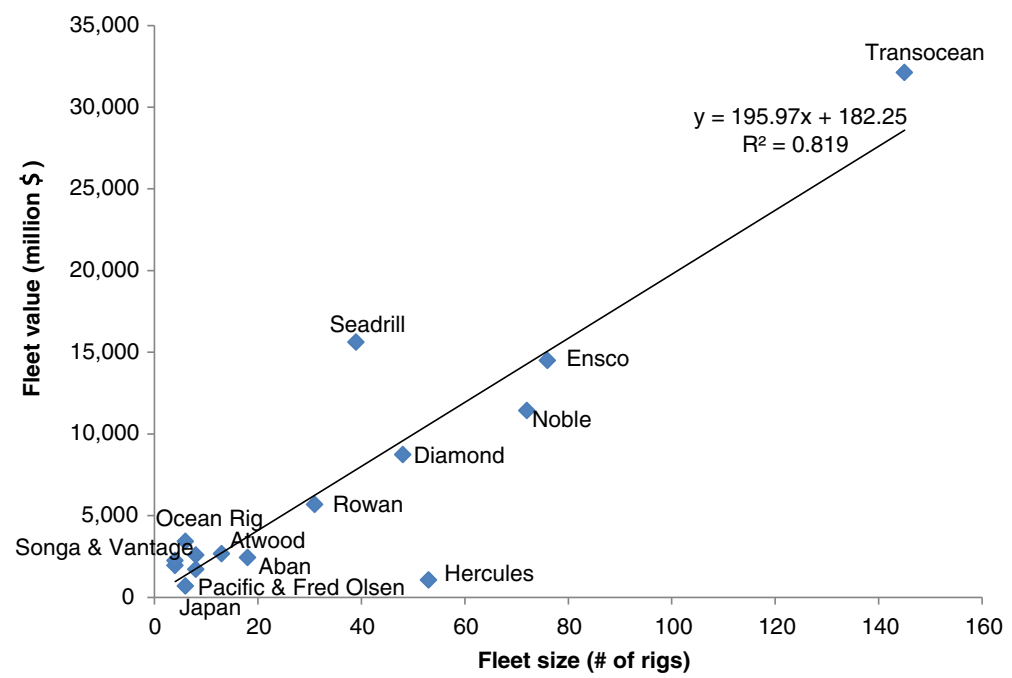

Fig. 7 Relationship between fleet size and fleet value in 2011. Data from Jefferies (2012)

were computed by region (Table 3). Older rigs received lower average dayrates than newer rigs in every regional market with a premium of $88 \%$ in the jackup market, $71 \%$ in the drillship market, and $25 \%$ in the semi market. Newer rigs were also more heavily utilized than older rigs, and companies with older fleets stacked their rigs a greater percentage of time (Fig. 8). Hercules and Diamond have particularly old fleets, whereas Seadrill has a younger fleet than the other large-cap firms, and these differences are likely to contribute to differences in market valuation vis a vis revenue generation potential.

\subsection{Diversification}

\subsubsection{Rig class}

Floaters generate larger net revenue than jackups in most regional markets and time periods, and drillers specialized in the floater market may have higher valuations than

Table 3 Average dayrates by rig age and region in 2010

\begin{tabular}{|c|c|c|c|c|c|c|}
\hline & \multicolumn{2}{|c|}{ Jackups (\$/day) } & \multicolumn{2}{|c|}{ Semis (\$/day) } & \multicolumn{2}{|c|}{ Drillships (\$/day) } \\
\hline & Pre-1986 & Post-1986 & Pre-1986 & Post-1986 & Pre-1986 & Post-1986 \\
\hline US GOM & 45,282 & 117,805 & 330,793 & 418,301 & 205,054 & 512,333 \\
\hline West Africa & 118,264 & 163,443 & 372,023 & 429,364 & 363,349 & 490,833 \\
\hline Persian Gulf & 100,947 & 167,343 & & & & \\
\hline North Sea & 112,051 & 201,928 & 360,766 & 479,985 & & 575,289 \\
\hline Southeast Asia & 128,924 & 137,440 & 305,715 & 470,781 & 252,846 & 455,113 \\
\hline World & 83,334 & 156,986 & 349,780 & 437,582 & 293,861 & 502,104 \\
\hline
\end{tabular}

Source: Data from RigLogix (2011) 


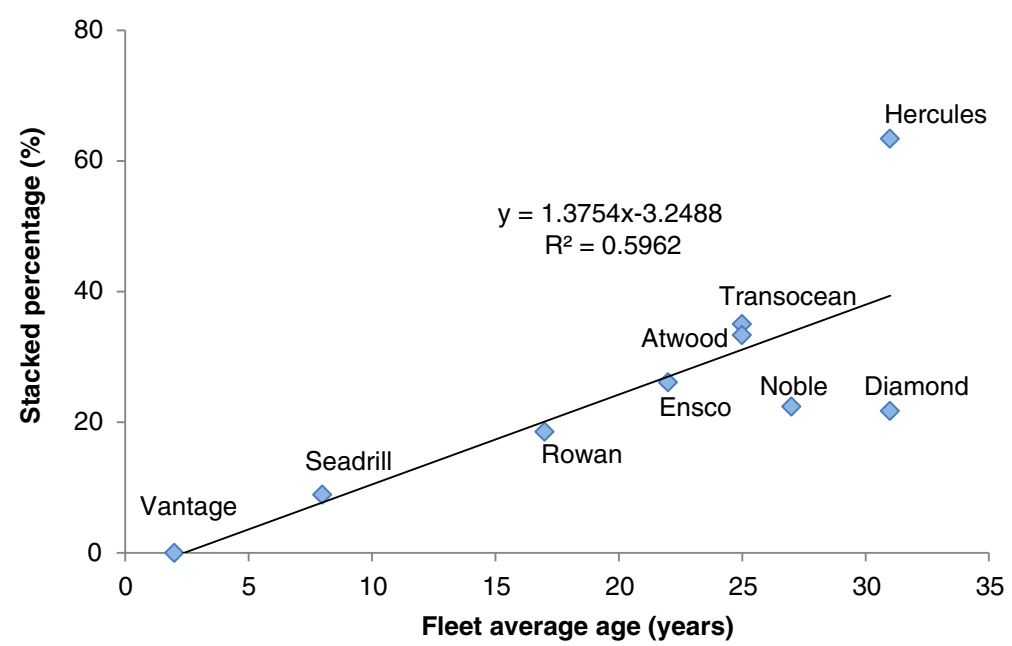

Fig. 8 Average fleet age and the proportion of the fleet stacked in December 2011. Data from Jefferies (2012)

jackup contractors. Performance data for Diamond and Transocean are summarized by market segment in 2011 (Table 4). For Transocean, ultra-deepwater and harshenvironment floaters were highly profitable due to high utilization and market conditions that commanded premium dayrates. High-specification shallow water jackups

Table 4 Transocean and Diamond performance statistics in 2011

\begin{tabular}{llllllr}
\hline Firm & Rig class $^{\mathrm{a}}$ & $\begin{array}{l}\text { Operating } \\
\text { costs }^{\mathrm{b}} \\
(\$ 1,000 / \text { day })\end{array}$ & $\begin{array}{l}\text { Dayrate } \\
(\$ 1,000 / \text { day })\end{array}$ & $\begin{array}{l}\text { Net revenue } \\
(\$ 1,000 / \text { day })\end{array}$ & $\begin{array}{l}\text { Utilization } \\
(\%)\end{array}$ & $\begin{array}{l}\begin{array}{l}\text { Expected net } \\
\text { revenue } \\
(\$ 1,000 / \text { year })\end{array} \\
\text { Transocean }\end{array}$ \\
& Ultra-deepwater & 199 & 533 & 334 & 79 & 81,056 \\
& Deepwater & 135 & 349 & 214 & 44 & 6,774 \\
& Harsh floaters & 171 & 450 & 279 & 95 & 93,623 \\
& Midwater floaters & 91 & 280 & 189 & 69 & 37,303 \\
& High-spec jackups & 81 & 114 & 33 & 71 & -22 \\
& Jackups & 29 & 97 & 68 & 49 & 6,674 \\
& Ultra-deepwater & 169 & 342 & 173 & 82 & 40,676 \\
& Deepwater & 119 & 416 & 297 & 94 & 99,295 \\
& Midwater floaters & 86 & 269 & 183 & 72 & 39,303 \\
& Jackups & 36 & 82 & 46 & 47 & 927 \\
\hline
\end{tabular}

Source: Financial reports

a Transocean defines ultra-deepwater as $>7,500 \mathrm{ft}$, deepwater as $>4,500 \mathrm{ft}$, and midwater as $<4,500 \mathrm{ft}$. Diamond defines ultra-deepwater as $>7,500 \mathrm{ft}$, deepwater as $>5,000 \mathrm{ft}$, and midwater as $<5,000 \mathrm{ft}$

${ }^{\mathrm{b}}$ Includes active and inactive costs

${ }^{\mathrm{c}}$ Calculated as annual revenues (dayrate times utilization times 365) minus annual costs (daily operating costs times 365) 
were the only market segment with negative net revenue. Diamond's deepwater fleet experienced higher dayrates than its ultra-deepwater fleet and was Diamond's most lucrative business segment. Floaters were more profitable than jackups in every segment, although the net earnings in Transocean's deepwater segment were relatively low due to low utilization and high-maintenance costs. Rigs in the midwater market generated approximately $\$ 40$ million per rig for both firms, whereas the jackup segment was only marginally profitable. Deepwater expected net revenue varied widely, from $\$ 7$ to 90 million (Transocean) to $\$ 40$ to 100 million per rig (Diamond).

\subsubsection{Specification}

Contractors diversify within a rig class by operating both high- and low-specification units (Fig. 9). In 2011, Transocean, Noble, Ensco, and Diamond were the only contractors to own units in every rig class. By contrast, all of Seadrill's units are high specification, and nearly all of Hercules' units are standard jackups. In most market conditions, high-specification rigs receive a dayrate premium, but high-specification rigs are also more expensive to operate, and may or may not be associated with higher net earnings. For example, for Transocean, high-specification jackups were not associated with a net earnings premium relative to standard jackups in 2011, while highspecification floaters had greater earnings than standard floaters.
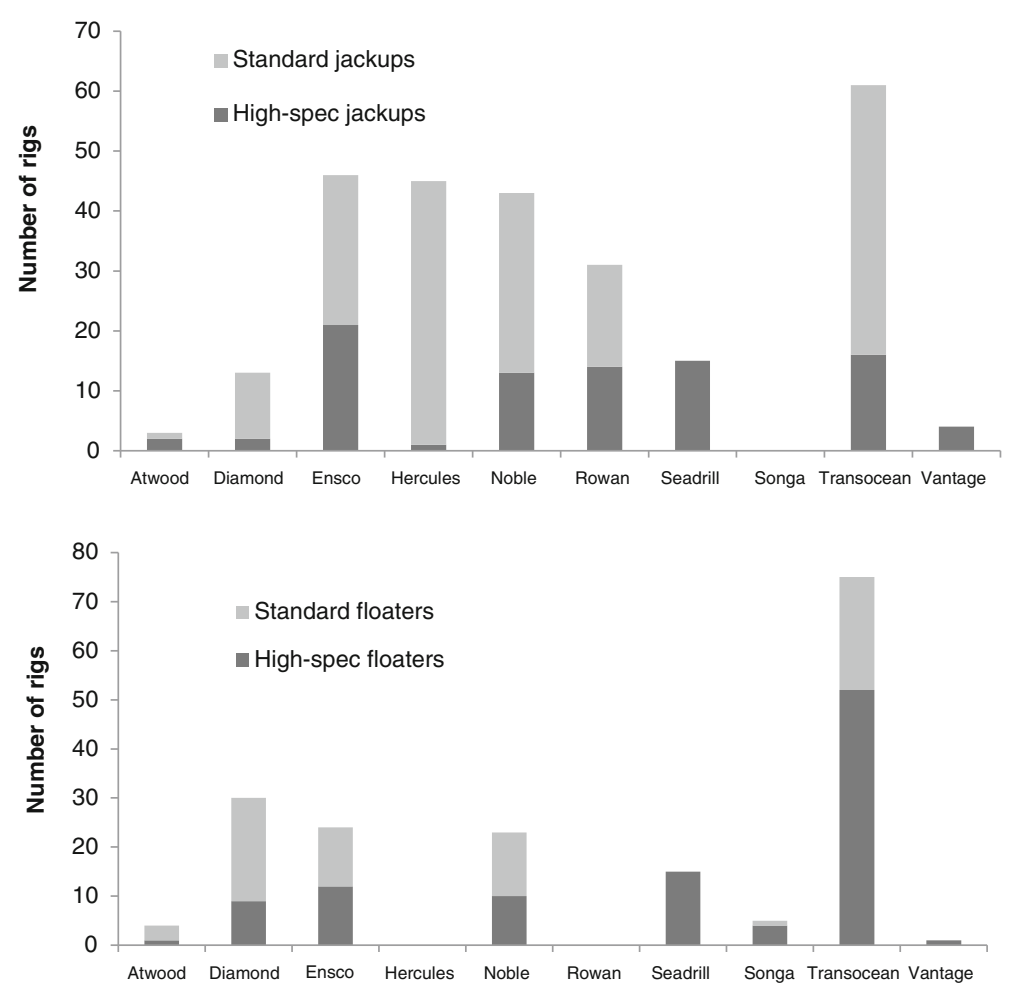

Fig. 9 Jackup and floater inventories in 2011. Data from financial reports 


\subsection{Geographic concentration}

Contractors position assets to capitalize on imbalances in supply and demand and achieve administrative cost reductions through economies of scale while building customer and governmental relationships (Corts 2008; Lee and Jablonowski 2010; Mascarenhas 1989). High concentration of rigs in a few countries also subjects firms to increased political, regulatory and financial risk. Following the Macondo blowout in the Gulf of Mexico, for example, the US government imposed a deepwater drilling moratorium which negatively impacted firms operating in the region. Firms with a high degree of concentration in the US GOM in 2010-2011 were disproportionately impacted by the moratorium.

Drilling contractors involved in international operations are subject to additional risks not generally associated with domestic operations, such as terrorist acts; war and civil disturbance; expropriation or nationalization of assets; renegotiation or nullification of contracts; changes in law or interpretation of existing law; assaults on property or personnel; foreign and domestic monetary policies; and travel limitations or operational problems caused by public health threats. There is a tradeoff between fleet diversity and market position, and firms balance the desire for a strong market position in some regions and markets against geographic and market diversity (Speer et al. 2009). Firms with larger fleets are more geographically diverse than firms with smaller fleets (Fig. 10), and as the number of countries in which a company operates increases, the proportion of total revenue from the four largest regions generally declines (Fig. 11).

Large firms are capable of balancing market position and diversity, while smaller firms are limited in the number of regions in which they can successfully compete (Table 5). Diamond Offshore was particularly dependent on the Brazilian market in 2011, and more than half of Hercules revenue were generated in the US GOM. Hercules and Rowan had the most concentrated geographic base while Noble and Transocean had the most geographically diverse revenue base. Firms that consistently

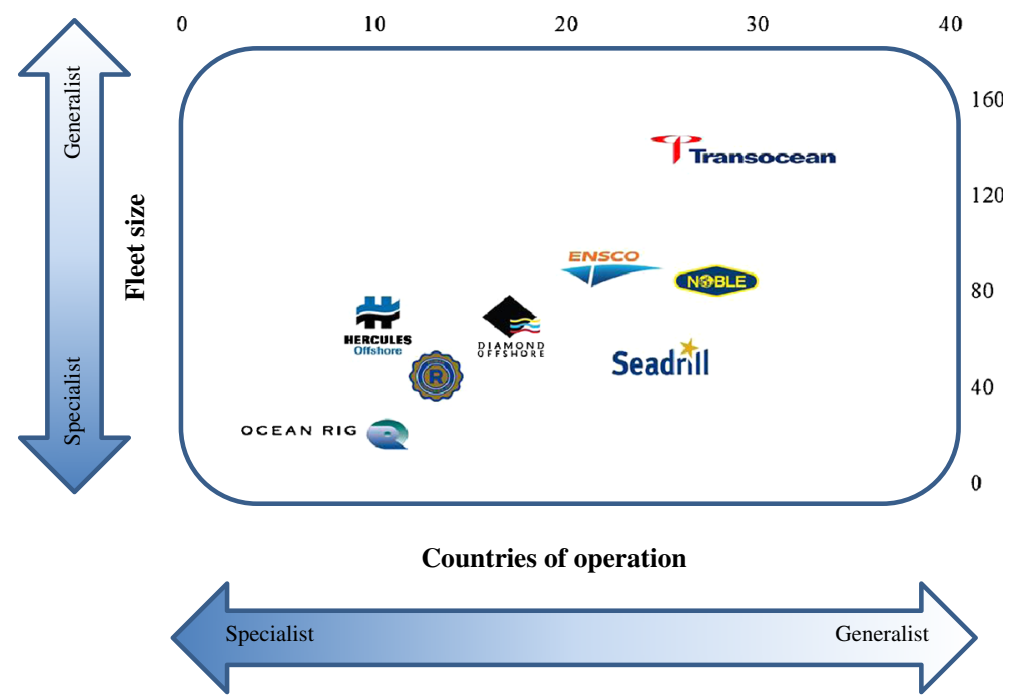

Fig. 10 Fleet size and the number of countries from which a contractor received revenue in 2011. Data from financial reports and Jefferies (2012) 

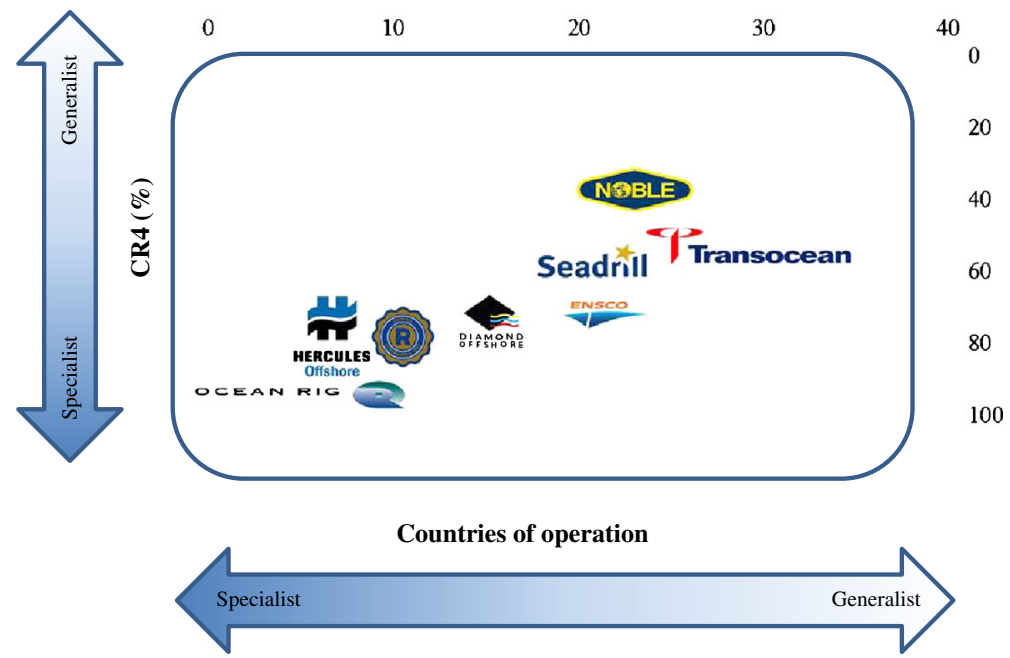

Fig. 11 Geographic specialization for selected contractors. CR4 is defined as the proportion of total revenue from the four largest countries. Data from financial reports and Jefferies (2012)

rely on competitive or declining regions may be undervalued relative to their peers. Hercules, for example, has historically been concentrated in the US GOM shallow water region, a declining market with low dayrates and utilization, whereas Seadrill has established itself as a significant presence in Brazil's deepwater region, a growing market with high utilization and limited competition.

Table 5 Drilling contractor revenues in million US dollars by region in 2011

\begin{tabular}{|c|c|c|c|c|c|c|c|c|}
\hline & Diamond & Ensco & Hercules & Noble & Rowan & Ocean Rig & Seadrill & Transocean \\
\hline Brazil & 1,641 & 583 & & 572 & & & 913 & 1,019 \\
\hline US GOM & 323 & 753 & 302 & 524 & 264 & & 202 & 1,975 \\
\hline UK & 152 & 240 & & 164 & 230 & & 56 & 1,211 \\
\hline Norway & & & & & 74 & & 966 & \\
\hline Angola & 318 & 250 & & & & & 337 & \\
\hline Mexico & 62 & 148 & 16 & 402 & 28 & & 49 & \\
\hline Saudi Arabia & & & 93 & 96 & 204 & & 127 & \\
\hline Nigeria & & & 98 & & & & 235 & \\
\hline China & & & & & & & 299 & \\
\hline Qatar & & & & 132 & 60 & & & \\
\hline India & & & 61 & 102 & & & & \\
\hline Other & 826 & 866 & 85 & 703 & 79 & 700 & 1008 & 4,937 \\
\hline Number of countries & 14 & 21 & 8 & 23 & 10 & 5 & 22 & 27 \\
\hline CR4 (\%) & 71 & 64 & 85 & 42 & 82 & 93 & 60 & 55 \\
\hline
\end{tabular}

Source: Financial reports

Note: Blank values do not indicate that the contractor received no revenue from the region, only that the revenue was not considered significant enough to list separately.

CR4 is defined as the proportion of total revenue from the four largest countries 


\subsection{Contract backlog}

Contract backlog is the value of a firm's existing contract commitments at the time of evaluation. Backlog includes the contracts rigs are currently working under as well as any future contracts and is calculated as the contract dayrate multiplied by the remaining contract duration for all rigs in a company's fleet. High backlogs are associated with stable revenues in the near to midterm which reduces risk for investors and may increase firm value.

\subsection{Customer concentration}

Contractors that derive the majority of their revenue from a small number of E\&P firms can create risk because the loss of a single client may eliminate a major source of revenue. Transocean is particularly diverse and its largest customer in 2011 only accounted for $10 \%$ of revenue. Atwood, Diamond, Hercules, Noble, and Rowan's major customer contributed between 25 and $35 \%$ of 2011 revenue and two customers comprised over half of total revenues for Atwood, Diamond, and Rowan. All else equal, firms with a diverse customer base are expected to be more valuable than firms with a limited customer base, but it is unlikely the market differentiates valuations according to customer concentration levels.

\subsection{Operating costs}

Net revenue associated with operating a rig is determined from the contract dayrate less the daily operating costs. Generally speaking, deepwater, high-specification, international rigs cost more to operate than shallow water, low-specification, domestic rigs

Table 6 Operating expenditures for jackups and floaters by contractor in 2011

\begin{tabular}{lllr}
\hline Rig class & Firm & Rig type & OPEX (\$/day) \\
\hline \multirow{2}{*}{ Jackups } & Transocean & High specification & 87,000 \\
& Hercules & Standard & 46,000 \\
& Atwood & Domestic & 32,000 \\
& & International & 47,000 \\
& Diamond & High specification & 64,000 \\
& & Standard & 44,000 \\
& Transocean & High specification & 55,000 \\
& & Standard & 52,000 \\
& & Ultra-deepwater & 150,000 \\
& Atwood & Deepwater & 137,000 \\
& & Midwater & 104,000 \\
& & Ultra-deepwater & 191,000 \\
& & Deepwater & 119,000 \\
\hline
\end{tabular}


(Table 6). Rig size and age, port infrastructure, scale economies related to a contractor's regional presence, market competition, and the availability of goods and services also impact operating cost. Firms with newer fleets, efficient logistic networks, and good management control tend to have lower operating cost than their competitors, which translates into higher net revenue and stronger valuations.

\subsection{Operating margin}

Operating margin is the ratio of operating income to revenue and is an aggregate measure of the cost structure of the firm. Firms with higher operating margins have larger net earnings per dollar of revenue than firms with lower margins. Firms with older fleets or a large number of stacked rigs are expected to have lower operating margins than firms with younger or more active rigs.

\subsection{Financial structure}

Rig construction is capital intensive and fleet additions are financed through a combination of debt and equity. The use of debt to finance growth increases the risk of default and may lead to variation in earnings as firms service debt. However, the use of debt also allows a firm to leverage its equity, potentially increasing the yield to investors.

\section{Methodology}

\subsection{Sample}

Market capitalization and enterprise value data from 15 publicly traded drilling contractors representing all large-cap firms and eight of the ten largest firms in the industry were assembled along with fleet values, revenues, earnings, contract backlog, financial metrics and fleet specification for the year ending 31 December 2011 (Table 7). The sample represented $63 \%$ of global drilling capacity in 2011, and all publicly traded firms where offshore drilling revenue accounted for a majority ${ }^{3}$ of total revenue. Drilling accounted for at least $95 \%$ of total revenue for all firms except Hercules where drilling accounted for $74 \%$ of revenue. Data were collected from annual reports, Bloomberg, and Jefferies.

\subsection{Evaluation period}

The time of assessment coincides with the release of end-of-year financial data on 31 December 2011. It is easy to incorporate time variation in the analysis, either by introducing time variables in the model specification, or by repeating the evaluation over different time periods. We prefer the later approach and describe model results for one year before (31 December 2010) and one year after (31 December 2012) the base period for sensitivity analysis.

\footnotetext{
${ }^{3}$ Maersk, Northern Offshore, Nabors, Saipem, COSL, Petrobras, ONGC, and a number of other national oil companies with drilling subsidiaries were excluded because their drilling revenues accounted for less than $60 \%$ of the firm revenues.
} 
Table 7 Financial metrics of selected publicly traded contractors in 2011

\begin{tabular}{lcccccc}
\hline Company & $\begin{array}{l}\text { Fleet value } \\
\text { (million \$) }\end{array}$ & $\begin{array}{l}\text { Backlog } \\
\text { (million \$) }\end{array}$ & $\begin{array}{l}\text { Debt } \\
\text { (million \$) }\end{array}$ & $\begin{array}{l}\text { Debt to } \\
\text { equity (\%) }\end{array}$ & $\begin{array}{l}\text { Operating } \\
\text { margin (\%) }\end{array}$ & $\begin{array}{l}\text { Dividends } \\
\text { (million \$) }\end{array}$ \\
\hline Seadrill & 15,613 & 12,600 & 10,428 & 174 & 42 & 1,431 \\
Transocean & 32,112 & 22,500 & 13,526 & 86 & 5 & 763 \\
Ensco & 14,496 & 9,666 & 5,050 & 46 & 38 & 269 \\
Diamond & 8,726 & 8,137 & 1,495 & 35 & 38 & 487 \\
Noble & 11,433 & 13,683 & 4,071 & 55 & 17 & 151 \\
Rowan & 5,680 & 3,065 & 1,134 & 26 & 17 & 0 \\
Atwood & 2,668 & 1,800 & 525 & 32 & 51 & 0 \\
Fred Olsen & 2,575 & 2,900 & 962 & 59 & 35 & 236 \\
Pacific Drill & 2,240 & 2,100 & 1,675 & 74 & -19 & 0 \\
Ocean Rig & 3,420 & 2,335 & 2,735 & 92 & 31 & 0 \\
Hercules & 1,065 & 432 & 845 & 93 & -3 & 0 \\
Japan Drill & 683 & 700 & 173 & 29 & 22 & 6 \\
Songa & 1,946 & 7,100 & 1,096 & 98 & 18 & 0 \\
Aban & 2,436 & 1,900 & 2,296 & 507 & 42 & 0 \\
Vantage & 1,703 & 1,000 & 1,246 & 179 & 23 & 0 \\
\hline
\end{tabular}

Source: Financial reports

\subsection{Valuation model}

Market capitalization (CAP) and enterprise value (EV) are hypothesized to follow linear relationships described by one or more combinations of fleet value (FLEET), revenue (REV), contract backlog (BL), floater and high-specification fleet proportions (PF, $\mathrm{PH})$, debt to equity ratio (DE), operating margin (OM), earnings before interest and taxes (EBIT), and dividend payments (DY). Seadrill and Transocean were significant outliers and were identified separately using indicator variables SDR and TRN, respectively (Table 8 ). The predictor variables were selected based on data availability and a subjective assessment of the factors most likely to impact company value (Table 8).

\subsection{Expectations}

\subsubsection{Fleet value}

Fleet value is the sum of the NAV of the individual rigs in a firm's fleet and is expected to be positively correlated with company valuation, REV, EBIT, and BL.

\subsubsection{Revenue}

Revenue is a function of regional dayrates, utilization, and fleet size and was used as a proxy for all three variables. Aban and Japan Drilling revenue were converted to US dollars using the exchange rate on 31 December 2011. Revenue are consistently reported and are expected to be positively correlated with company valuation, EBIT, FLEET, and BL. 
Table 8 Market valuation model variable definitions and data sources

\begin{tabular}{llll}
\hline Variable & Definition & Unit & Data source \\
\hline CAP & Market capitalization & Million \$ & Bloomberg \\
EV & Enterprise value & Million \$ & Bloomberg \\
FLEET & Fleet value & Million \$ & Jefferies \\
REV & Revenue & Million \$ & Bloomberg \\
BL & Backlog & Million \$ & Financial reports \\
PF & Proportion of floaters & $\%$ & Financial reports \\
PH & Proportion of high-spec rigs & $\%$ & Financial reports \\
DE & Debt to equity ratio & $\%$ & Bloomberg \\
OM & Operating margin & $\%$ & Bloomberg \\
SDR & Seadrill indicator & 1 if Seadrill, 0 otherwise & \\
TRN & Transocean indicator & 1 if Transocean, 0 otherwise & \\
EBIT & Earnings & Million \$ & Bloomberg \\
DY & Dividend yield & $\%$ & Bloomberg \\
\hline
\end{tabular}

\subsubsection{Backlog}

Backlog data was collected from annual reports at the time of assessment and represents the future revenue potential of a company and is expected to be positively correlated with firm valuation.

\subsubsection{Fleet specification}

The proportion of high-specification rigs and floaters was derived from financial reports. High-specification rigs usually achieve dayrate premiums over low-specification rigs, and floaters often realize higher utilization and dayrates than jackups. Measures of firm value are expected to be positively correlated with the proportion of the fleet that is composed of high-specification or floating rigs.

\subsubsection{Debt to equity ratio}

Debt to equity was calculated as the total debt divided by shareholder equity using data from Bloomberg. Highly leveraged firms have higher fixed charges in the form of interest payments relative to discretionary outlays such as dividends. The higher the debt to equity ratio, the greater financial risk, and the lower the expected company valuation.

\subsubsection{Operating margin}

Operating margin is the ratio of operating income to revenue expressed as a percentage and is expected to be positively correlated with firm valuation. 


\subsubsection{Indicator variables}

Transocean drilled the Macondo well that blew out on 20 April 2010 and by 31 December 2011 its liabilities were not resolved. Seadrill has a young, highspecification fleet, high-utilization rates, and a low-cost structure relative to its peers and has been consistently rewarded by the market in its valuation. Indicator variables are employed to distinguish these companies from the other firms as they appear as outliers.

\subsubsection{Earnings}

Earnings before interest and taxes is a function of firm revenue and expenses and is expected to be positively correlated with FLEET, REV, BL, and firm value.

\subsubsection{Dividends}

Drilling contractors often pay dividends to return cash to investors. Data on total cash dividends were collected from Bloomberg and normalized by the market capitalization to derive the dividend yield. High dividends may attract investors, potentially increasing the share price, but dividends and share price are often inversely related. The impact of dividends on contractor valuation is uncertain.

\subsection{Correlation matrix}

Backlog, fleet value and revenue were all correlated, and dividend yield was weakly correlated with earnings (Table 9). All other predictor variables were not correlated. Revenue and backlog are measures of current and future income and are expected to be related. Fleet value is determined in part by backlog, and firms with more valuable fleets should be able to generate larger backlogs and revenue. Earnings and other predictors of firm value do not demonstrate high correlations because several large firms (e.g., Noble and Transocean) had relatively low earnings whereas several smaller firms (e.g., Atwood and Fred Olsen) had high earnings relative to their revenue during the period.

Table 9 Correlation matrix among predictor variables in 2011

\begin{tabular}{lrrrrrrrrr}
\hline & FLEET & REV & BL & PF & PH & DE & OM & EBIT & DY \\
\hline FLEET & 1 & & & & & & & \\
REV & 0.98 & 1 & & & & & & & \\
BL & 0.95 & 0.93 & 1 & & & & & & \\
PF & -0.05 & -0.02 & 0.06 & 1 & & & & & \\
PH & 0.03 & -0.05 & 0.05 & 0.32 & 1 & & & & \\
DE & -0.10 & -0.09 & -0.12 & -0.25 & 0.25 & 1 & & & \\
OM & -0.03 & -0.02 & -0.04 & -0.01 & -0.06 & 0.22 & 1 & & \\
EBIT & 0.49 & 0.51 & 0.51 & 0.05 & -0.08 & 0.01 & 0.52 & 1 & \\
DY & 0.46 & 0.54 & 0.47 & 0.29 & 0.20 & -0.12 & 0.30 & 0.71 & 1 \\
\hline
\end{tabular}



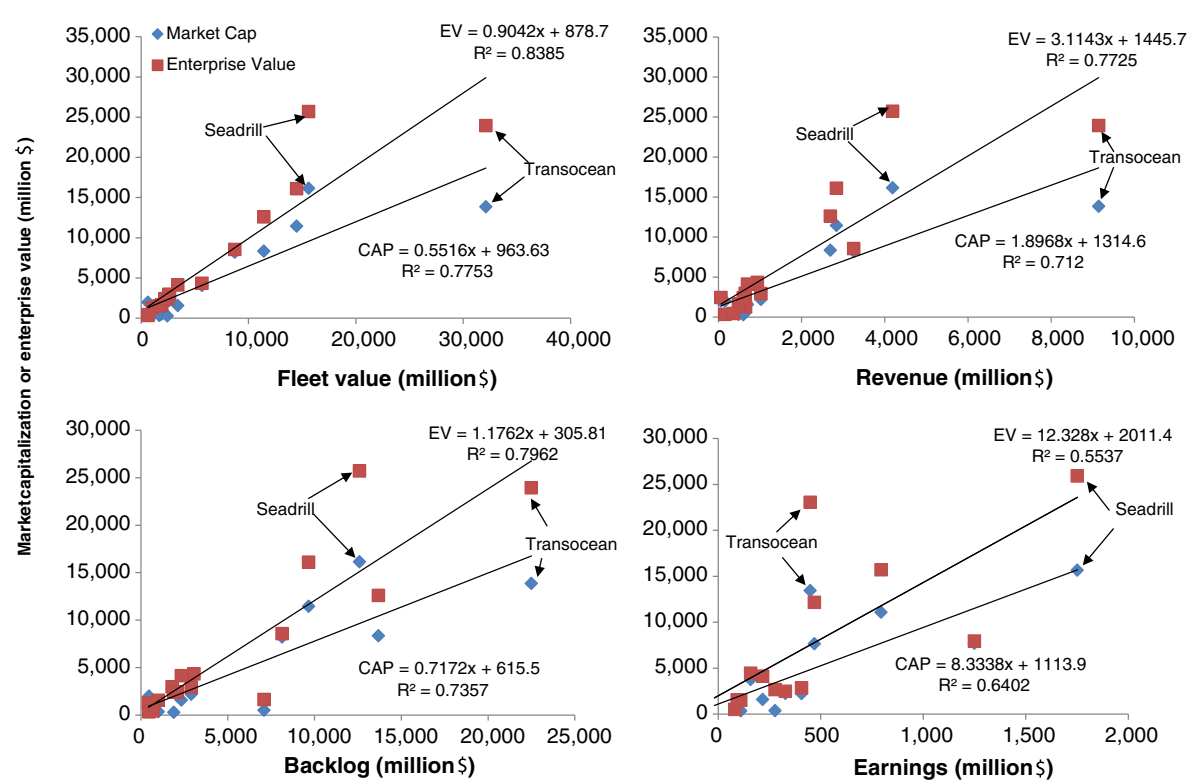

Fig. 12 Market capitalization and enterprise value relations. Data from financial reports and Jefferies (2012)

\section{Model results}

\subsection{Single-variable models}

Fleet value, revenue, earnings and backlog were significant predictors of enterprise value and market capitalization in single-factor models (Fig. 12). Fleet value, revenue, and backlog were influential predictors, accounting for approximately $70-80 \%$ of the variation in firm value, compared with earnings which predicted between 55 and $65 \%$. Transocean and Seadrill are outliers in all the relationships, and with the exception of earnings, Transocean is undervalued and Seadrill is overvalued relative to the industry average. Operating margin, dividend yield, fleet specification, and debt equity ratio were not useful predictors in the relationships.

Offshore drilling contractors often have large debt loads, and as a result, EV is usually greater than market CAP. ${ }^{4}$ For each $\$ 1$ increase in FLEET in 2011, market CAP increased on average $\$ 0.55$ and $\mathrm{EV}$ increased $\$ 0.90$; for each $\$ 1$ increase in BL, market CAP increased by $\$ 0.72$ and EV increased by $\$ 1.17$; for each $\$ 1$ increase in REV, market CAP increased by $\$ 1.89$ and $E V$ increased by $\$ 3.11$; and for each $\$ 1$ increase in earnings, market CAP increased by $\$ 8.3$ and $\mathrm{EV}$ increased by $\$ 12.3$.

\subsection{Multivariable models}

\subsubsection{Market capitalization}

All parameters of the multivariable market capitalization models are significant $(p<0.05)$ except the intercept terms (Table 10). Fleet specifications, operating margin,

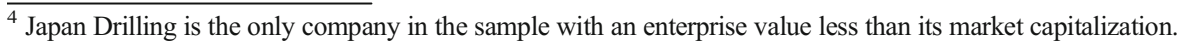


Table 10 Selected models of market capitalization in 2011

$\mathrm{CAP}=a+b \cdot \mathrm{FLEET}+c \cdot \mathrm{REV}+d \cdot \mathrm{BL}+g \cdot \mathrm{DE}+i \cdot \mathrm{SDR}+j \cdot \mathrm{TRN}+k \cdot \mathrm{EBIT}$

\begin{tabular}{lcclllllll}
\hline Model & $a$ & $b$ & $c$ & $d$ & $g$ & $i$ & $j$ & $k$ & $R^{2}$ \\
\hline A & -36.4 & $0.66^{*}$ & & & $-3.5^{*}$ & $3,117^{*}$ & $-8,050^{*}$ & $1.7^{*}$ & 0.99 \\
B & -439 & $0.78^{*}$ & & & & $3,858^{*}$ & $-11,298^{*}$ & & 0.98 \\
C & 243 & & & $0.68^{*}$ & & $6,813^{*}$ & $-2,168^{*}$ & & 0.83 \\
D & -343 & & $2.99^{*}$ & & & $3,459^{*}$ & $-13,571^{*}$ & & 0.92 \\
\hline
\end{tabular}

${ }^{*} p<0.05$, statistical significance

and dividend yield did not add predictive power to the models and were not included. Model A yielded the best fit because indicator variables were used to control for the two outlier firms. When the debt equity ratio and earnings variables were removed, the model fit declined negligibly, and as model B explains essentially the same amount of variation in market cap as model A with two less predictor variables, it may be preferred. Backlog (model C) and revenue (model D) were not as good predictors as fleet value, but relationships remained significant.

\subsubsection{Enterprise value}

All parameters of enterprise value regression models were statistically significant $(p<0.05)$ except the intercept terms (Table 11). Fleet specifications, operating margin, debt to equity ratio, earnings, and dividend yield did not add predictive power and were not included. The inclusion of the Seadrill and Transocean indicator variables improved the model fits over the singlevariable relation as expected. Fleet value was a better predictor than revenue (model B), backlog (model C), or earnings (model D). In the backlog model, the Transocean indicator variable was not significant suggesting that Transocean is not undervalued with respect to its backlog. In the earnings model, the Seadrill indicator was not significant and the Transocean indicator was positive, suggesting that Seadrill is appropriately valued while Transocean is overvalued relative to their earnings.

Table 11 Selected models of enterprise value in 2011

\begin{tabular}{|c|c|c|c|c|c|c|c|c|}
\hline Model & $a$ & $b$ & $c$ & $d$ & $i$ & $j$ & $k$ & $R^{2}$ \\
\hline A & -205 & $1.05^{*}$ & & & $9,663^{*}$ & $-10,559^{*}$ & & 0.99 \\
\hline B & 2,114 & & $3.77 *$ & & $9,885^{*}$ & $-11,619^{*}$ & & 0.92 \\
\hline $\mathrm{C}$ & 466 & & & $0.98^{*}$ & $13,037^{*}$ & & & 0.91 \\
\hline D & 955 & & & & & $16,618^{*}$ & $12.2^{*}$ & 0.80 \\
\hline
\end{tabular}

${ }^{*} p<0.05$, statistical significance 


\subsection{Temporal patterns}

To determine if the observed trends were robust over time, the valuation of the same firms was investigated one year before and one year after the primary analysis (31 December 2010 and 31 December 2012). Only variables that were found to be useful predictors in the 2011 data (REV, EBIT, FLEET, SDR, TRN) were investigated. All other methods were identical.

\subsubsection{Year 2010}

In 2010, a single-variable model using fleet value as a predictor explained $97 \%$ of the variation in market capitalization and $93 \%$ of the variation in enterprise value. As in the 2011 data, REV, EBIT and BL were also significant predictors in single-variable models with high values of model fit. Transocean and Seadrill indicator variables did not add significant predictive power to the models. Thus, multifactor models are not necessary to model firm valuation.

As the date of the analysis (31 December 2010) is after the Macondo oil spill, it is surprising that an indicator variable for Transocean is not required. Transocean's share price declined through the spring and summer of 2010 but largely recovered in the fall of 2010, and by December of 2010 was approximately at its pre-spill level. However, the market value of the firm declined again in 2011 as uncertainty about its legal situation grew.

The fact that Seadrill is not an outlier in 2010 but was an outlier in 2011 is mostly due to a change in the slope of the regression relationships rather than a change in company valuation. Seadrill's market capitalization was $97 \%$ of its fleet value in 2010 and $100 \%$ of its fleet value in 2011 . However, in 2010, the average firm in the sample had a market capitalization of $87 \%$ of its fleet value which declined to $78 \%$ of fleet value in 2011. Thus, while Seadrill's position remained constant, the slope of the relationship between fleet value and market capitalization for all other firms declined. A similar effect occurred for enterprise value (Fig. 13).

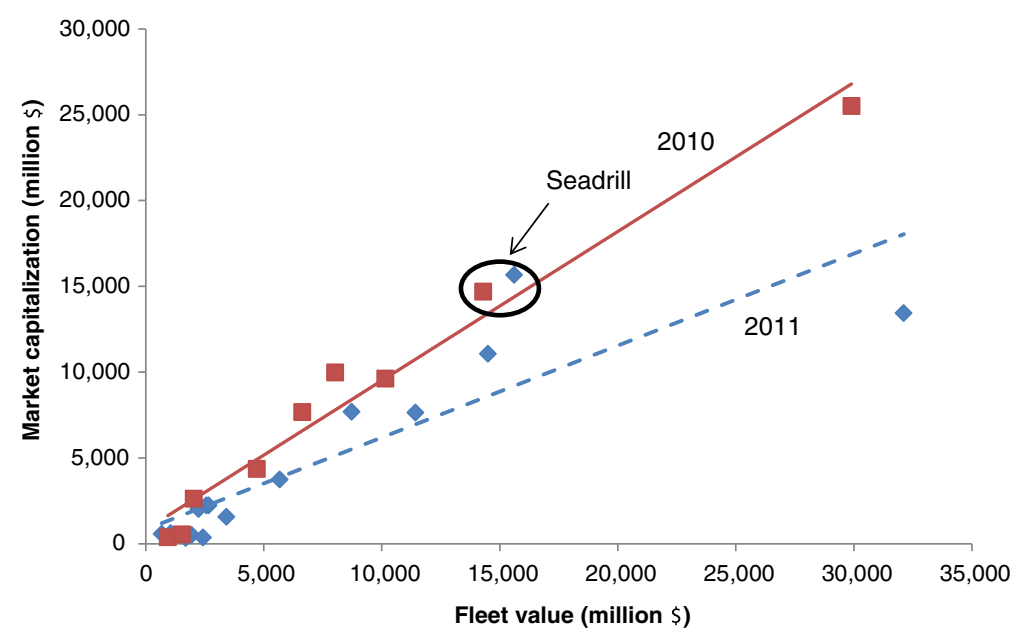

Fig. 13 Fleet value and market capitalization in 2010 and 2011 
Table 12 Best-fit models of market capitalization and enterprise value in 2010 and 2012

\begin{tabular}{|c|c|c|c|c|c|c|}
\hline \multirow[t]{2}{*}{ Year } & \multicolumn{6}{|c|}{ Value $=a+b \cdot \operatorname{FLEET}+i \cdot \mathrm{SDR}+j \cdot \mathrm{TRN}$} \\
\hline & Value & $a$ & $b$ & $i$ & $j$ & $R^{2}$ \\
\hline 2010 & $\mathrm{MC}$ & 814 & $0.86^{*}$ & & & 0.97 \\
\hline 2010 & $\mathrm{EV}$ & 173 & $1.21 *$ & & & 0.93 \\
\hline 2012 & $\mathrm{MC}$ & -148 & $0.67 *$ & $4,052 *$ & $-6,801 *$ & 0.97 \\
\hline 2012 & EV & 60 & $0.93^{*}$ & $9,638^{*}$ & $-6,062 *$ & 0.99 \\
\hline
\end{tabular}

${ }^{*} p<0.05$, statistical significance

\subsubsection{Year 2012}

The 2012 model results are generally similar to the results of the 2011 models. In single-variable models, FLEET is the best predictor of firm value in 2012, but BL, REV, and EBIT are also significant predictors. Without indicator variables, FLEET explains approximately $83 \%$ of the variation in EV and CAP. Debt to equity ratio is not significant in either valuation models.

Like the 2011 data, 2012 models improve when indicator variables for Seadrill and Transocean are included. Unlike the 2011 models, when fleet value was combined in multifactor models with the indicator variables and other quantitative predictors, the other predictors, became nonsignificant. Thus, the best models contained FLEET and indicator variables but no other predictors (Table 12).

\section{Discussion}

\subsection{Fleet value}

Fleet value is the single best predictor of firm value for the variables examined, and after controlling for Seadrill and Transocean, predicted essentially all of the variation in enterprise value and market capitalization for the three years examined during the period 2010-2012. Fleet value is a better predictor than REV, BL or EBIT. In aggregate, market capitalization represented $78 \%$ of the fleet value whereas enterprise value was $105 \%$ of fleet value suggesting that the discounted value of the fleet most closely approximates enterprise value.

\subsection{Debt to equity ratio}

Debt to equity ratio was a significant predictor of market capitalization but not enterprise value. As expected, the sign of $\mathrm{DE}$ was negative indicating that firm value decreases with increasing debt loads, however, the impact on model fit was small. The absence of DE as a useful predictor of enterprise value may partially reflect the fact that debt is already accounted for in its specification. 


\subsection{Transocean}

Transocean's 2011 and 2012 valuation discount is large but consistent with the market capitalization decline experienced after the 2010 Macondo blowout (Anderson et al. 2011). Prior to the blowout in April 2010, Transocean's market capitalization was approximately $\$ 31.5$ billion, but by June 2010, Transocean's market capitalization had declined to $\$ 16.4$ billion (Lee and Garza-Gomez 2012). In 2011, Transocean recorded a loss of $\$ 6.2$ billion related to the Macondo blowout, primarily due to goodwill impairment. ${ }^{5}$ In January 2013, Transocean agreed to plead guilty to one criminal misdemeanor violation of the Clean Water Act and pay a \$100 million fine, \$1 billion in fines for civil violations related to the Clean Water Act, and \$300 million for oil spill response and habitat rehabilitation (Johnson and Fisk 2013).

\subsection{Seadrill}

Seadrill has a young, high-specification fleet that has maintained high-utilization rates and a low-cost structure relative to its peers. Transocean, Diamond, Noble, and Ensco all maintain larger, more diverse fleets with a mix of old and new units. In depressed markets, older units are frequently idle for a greater percentage of time relative to new units, and may represent a net carrying cost to the firm. Seadrill has very few old units and realizes a higher operating margin than its large-cap peers. While the operating margin was not a significant predictor in the analysis, investors may still use operating margin as an indicator of firm value.

In 2011, Seadrill rigs were working in over 20 countries and every major market and the US GOM market only accounted for $5 \%$ of its revenue. By contrast, the US GOM accounted for $26 \%$ of Ensco, $22 \%$ of Transocean, $19 \%$ of Noble, and $10 \%$ of Diamond revenue, and the stocks of these companies reacted less favorably to the drilling moratorium after the Macondo oil spill. Seadrill also has a higher debt load relative to its peers and has used debt to fund an aggressive newbuild campaign which is in contrast to the more conservative large-cap peers (DeLuca 2001). In 2011, Seadrill paid a dividend yield of $9.1 \%$ compared with $5.6 \%$ for Transocean, $6.3 \%$ for Diamond, $2.4 \%$ for Ensco, and $1.9 \%$ for Noble.

\subsection{Limitations}

The ability to construct robust multivariable models is limited by the small sample size and homogenous nature of firms, but because we evaluated all publicly traded firms for which data were available, the model results are representative of general trends and relations in the industry. The models are easily extended across time with additional data collection and analysis. For state-owned firms or companies that generate a significant portion of their revenue from other business segments these models will not translate.

\footnotetext{
${ }^{5}$ Goodwill impairment occurs when the fair market value of goodwill exceeds the carrying value. Under accounting rules, companies review their goodwill annually by projecting profits and analyzing the market values of similar assets. If the profit outlook worsens or market value declines, a company is supposed to write down the value of the goodwill, booking an expense equal to the reduction. As write downs do not involve cash flow or operations, they are often ignored by analysts and investors (Thurm 2012).
} 
Market valuations are dynamic and it is unlikely that Seadrill will remain overvalued and Transocean undervalued relative to their fleet value for an extended period of time. Transocean's liability position should be resolved by 2015 which will reduce the market discount of its current valuation if all other conditions remain constant, and it will be interesting to watch the evolution of Seadrill's market premium. If Seadrill and Transocean regress towards the industry mean, single-variable models will likely adequately reflect industry conditions.

\section{Conclusions}

Market capitalization and enterprise value of offshore drilling contractors is reasonably predicted by fleet value, and fleet value is a better predictor than any other singlevariable examined, however, backlog, earnings and revenue were also significant predictors of company value. In 2011 and 2012, the models improve when two outliers in the data, Seadrill and Transocean, are accounted for individually. Relative to the other firms in the sample, Seadrill is overvalued while Tranocean is undervalued, and likely reasons for the departures from industry averages were traced back to operating events and unique characteristics of the companies rig fleet. Ultimately, stock price discrepancies are due to investors' perception of the potential future earnings of the firms. Transocean's discount is due to the market perception of liabilities associated with the 2010 Macondo blowout, and Seadrill's premium reflects its high-specification, globally diverse fleet, and high dividend payouts.

A cash flow model to estimate rig NAV was presented and compared with a business intelligence firm. Although results were only presented for two rigs owned by one drilling contractor, the procedure is completely general and is expected to broadly reflect industry estimates. NAV are based upon imperfect information and uncertain futures and are themselves uncertain. NAV estimates are primarily impacted by dayrates, utilization, and operating costs assumptions.

Fleet value is the sum of the NAV of each rig in the firm's fleet and is strongly correlated with firm value in the same way that oil and gas company valuations are correlated to reserves and production estimates (Kaiser 2013). Simple cash flow models are adequate for determining fleet value, and subsequently, contractor valuation. The fact that fleet value is a good predictor of firm value may not come as a surprise to industry insiders, but we are not aware of academic work exploring the relations described in this paper. More complex models of firm valuation using dayrates, utilization rates, and time series could be developed; however, simple models based on NAV appear adequate. Additional analysis investigating the relationship between fleet value and firm value over time is warranted.

The analysis focused only on the most important factors expected to have the greatest impact on firm valuation. Other factors could be investigated but data limitations are likely to preclude quantitative analysis. For example, given a larger sample size or an alternative analytic method, it may be possible to control for the effects of fleet size on diversity. Since the financial crisis began in 2009, a large and persistent valuation gap has existed between US E\&P companies and Euro Zone counterparts (Denning 2012), and it is possible that Euro zone drilling contractors (Fred Olsen and Songa) are being penalized as a European denominated share since most services are priced in US dollars. Other financial metrics such as annual return on average capital employed may also provide useful correlations. 


\section{Appendix A. Net asset value}

Net cash flow

NAV of a rig is estimated from the discounted net cash flow over its remaining life:

$$
\mathrm{NAV}=\sum_{\mathrm{t}=0}^{\mathrm{t}=\mathrm{L}} \frac{\mathrm{NCF}_{\mathrm{t}}}{(1+\mathrm{D})^{\mathrm{t}}}
$$

where $\mathrm{NCF}_{t}$ is the net cash flow in year t, D is the company discount rate, and $\mathrm{L}$ is the remaining life of the rig. If the rig is assumed to have an operational life of T years and is currently A years old, the remaining life of the rig over which cash flow is generated is given by $\mathrm{L}=\mathrm{T}-\mathrm{A}$.

Model components

Net cash flow is composed of income minus operating expenses and taxes:

$$
\mathrm{NCF}_{\mathrm{t}}=\text { Income }_{\mathrm{t}}-\mathrm{OPEX}_{\mathrm{t}}-\text { Taxes }_{\mathrm{t}}
$$

Income is based on the rig dayrate $\left(\mathrm{DR}_{\mathrm{t}}\right)$ and the portion of the year the rig is earning income $\left(\mathrm{U}_{\mathrm{t}}\right)$ normalized by the number of days per year:

$$
\text { Income }_{\mathrm{t}}=\mathrm{DR}_{\mathrm{t}} \cdot \mathrm{U}_{\mathrm{t}} \cdot 365
$$

Operating costs are given by:

$$
\mathrm{OPEX}_{\mathrm{t}}=\mathrm{O}_{\mathrm{t}} * 365
$$

where $\mathrm{O}_{\mathrm{t}}$ denotes the average daily costs of labor, maintenance, insurance, administration, and related costs. Operating expenses change with working status and coldstacked rigs will experience lower daily operating costs than active rigs. Similarly, newer rigs typically cost less to operate and maintain than old rigs.

Net income is taxed at rate $\mathrm{X}$ and discounted for depreciation. Straight line depreciation is assumed based on the initial capital costs $(C)$ of the rig:

$$
\text { Taxes }_{\mathrm{t}}=\left(\text { Income }_{\mathrm{t}}-\mathrm{OPEX}_{\mathrm{t}}-\frac{\mathrm{C}}{25}\right) \cdot \mathrm{X}
$$

A company creates value for its shareholders when it invests in projects that yield results above the cost of capital it utilizes for the investment. The discount rate used for the calculation of present value is the risk-adjusted cost of capital. Most contractors expect investments yield some minimum amount above the weighted average cost of capital. Companies may also impose an additional risk premium if the project risks differ from the risks associated with the average activity of the company (Abrams 2010; Shrieves and Wachowicz 2001). 


\section{Illustration}

The NAV of a $\$ 200$ million jackup rig with $\$ 60,000$ /day operating expenses and a $15 \%$ discount and tax rate is computed (Table 13). The rig is assumed to have a design life of 25 years. NAV is computed holding utilization constant at $90 \%$ and varying dayrate, and by holding dayrate constant at $\$ 120,000$ /day and varying utilization, for the rig at 5,10 , and 20 years old. Operating cost is assumed constant over the life of the asset. Dayrate and utilization is assumed independent of the age of the rig.

NAV increases with increasing dayrates, utilization, and remaining life (Fig. 14). At low dayrates and utilization (80,000/day, $55 \%$ ), NAV is less than $\$ 20$ million, and the difference in NAVs for old versus newer rigs is negligible. As the dayrate and utilization increases, the difference in NAV increases depending on the remaining life of the rig. For 5- and 10-year-old rigs, the difference in NAV is small, but for 20-year-old rigs, the time remaining to generate income is limited and NAVs are steeply discounted. At $90 \%$ utilization and $\$ 120,000 /$ day, NAVs range from $\$ 60$ million $(A=20$ years) to $\$ 100$ million $(\mathrm{A}=5$ and 10 years $)$.

\section{Industry comparison}

Transocean's Galaxy II and Galaxy III jackups are rated at $400 \mathrm{ft}$ water depth and were delivered by Keppel in 1998 and 1999. In 4Q2011, the rigs were operating in the North Sea under dayrate contracts of $\$ 167,000$ and $\$ 144,000 /$ day. The NAVs of the rigs were estimated using the model parameters in Table 13 with the exception of age and contract dayrates which were obtained circa 2011. The NAV of Galaxy II is estimated to be \$166 million and the NAV of Galaxy III is estimated at \$133 million at the time of evaluation 1Q2102 (Table 14).

Asset valuations match closely with Jefferies, but our values are slightly lower reflecting differences in model assumptions. Jefferies' historic NAV estimates for the Galaxy II and Galaxy III follow similar but not identical trends, indicating similarity in rigs and the regional market (Fig. 15). Rigs of the same specification and class operating in the same region typically have closely correlated NAVs, and the durability of an NAV estimate depends upon the length of the contract and market conditions.

Table 13 NAV cash flow model parameterization for a \$200 million jackup rig

\begin{tabular}{llll}
\hline Variable & Unit & Description & Value \\
\hline $\mathrm{O}_{\mathrm{t}}$ & $\$ /$ day & Operating costs & 60,000 \\
$\mathrm{DR}_{\mathrm{t}}$ & $\$ /$ day & Dayrate & Variable \\
$\mathrm{L}$ & year & Remaining life of the rig & $25-\mathrm{A}$ \\
$\mathrm{U}_{\mathrm{t}}$ & $\%$ & Utilization rate & Variable \\
$\mathrm{X}$ & $\% /$ year & Tax rate & 15 \\
$\mathrm{D}$ & $\% /$ year & Discount rate & 15 \\
$\mathrm{~A}$ & year & Age of the rig & 5,10, or 20 \\
$\mathrm{C}$ & \$ million & Initial capital expenditures & 200 \\
\hline
\end{tabular}



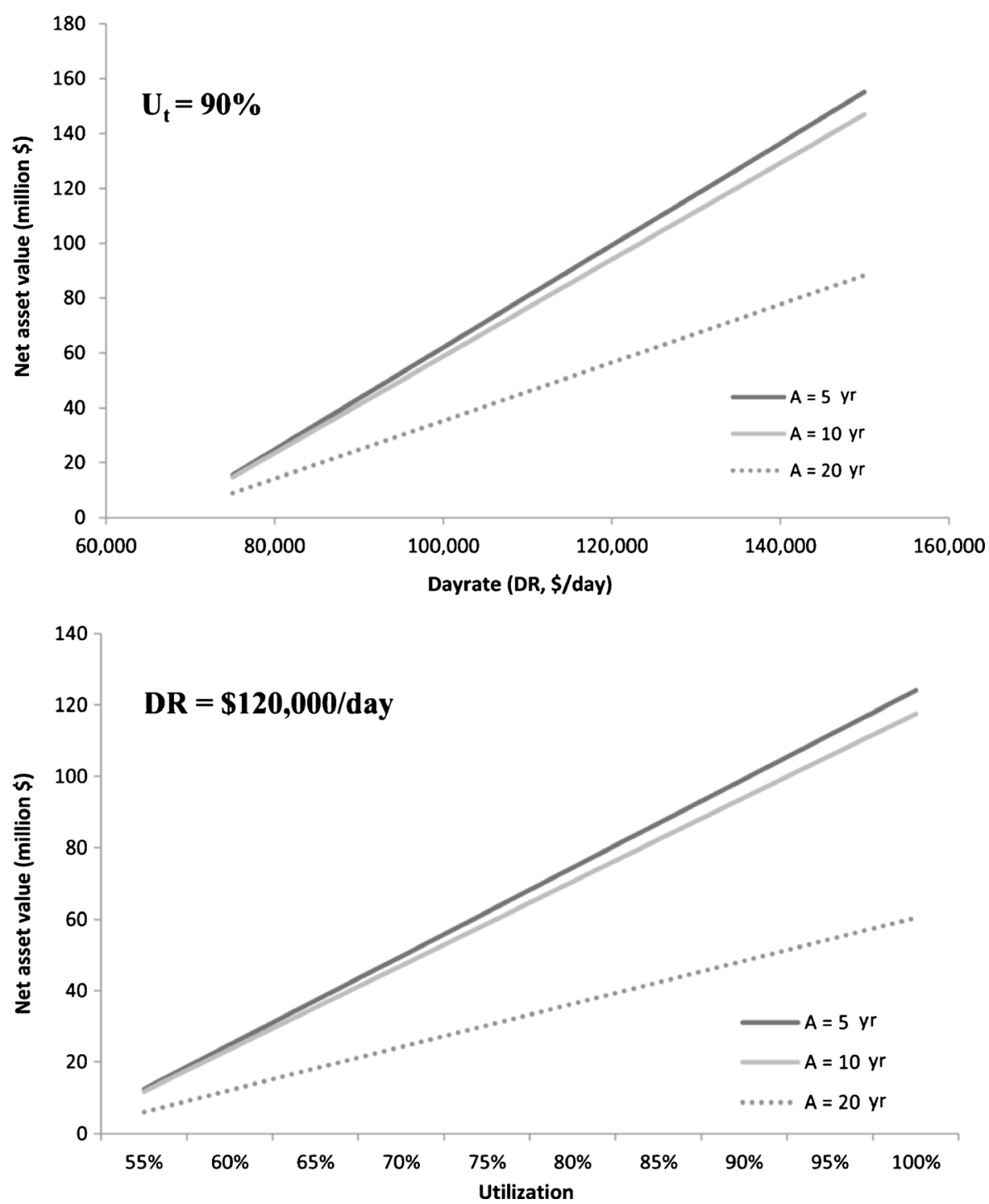

Fig. 14 Relationship between NAV, dayrates and utilization for jackups of different ages

Table 14 Comparison of NAV estimates for two standard $400 \mathrm{ft}$ jackup rigs in 4Q2011

\begin{tabular}{lllllll}
\hline & Age & $\begin{array}{l}\text { Dayrate } \\
\text { (\$/day) }\end{array}$ & $\begin{array}{l}\text { Utilization } \\
\text { rate }(\%)\end{array}$ & $\begin{array}{l}\text { Discount } \\
\text { rate }(\%)\end{array}$ & $\begin{array}{l}\text { Authors NAV } \\
\text { (million \$) }\end{array}$ & $\begin{array}{l}\text { Jefferies NAV } \\
\text { (million \$) }\end{array}$ \\
\hline Galaxy II & 14 & 167,000 & 90 & 15 & 166 & 170 \\
Galaxy III & 13 & 144,000 & 90 & 15 & 131 & 156 \\
\hline
\end{tabular}

Source: Jefferies (2008) 

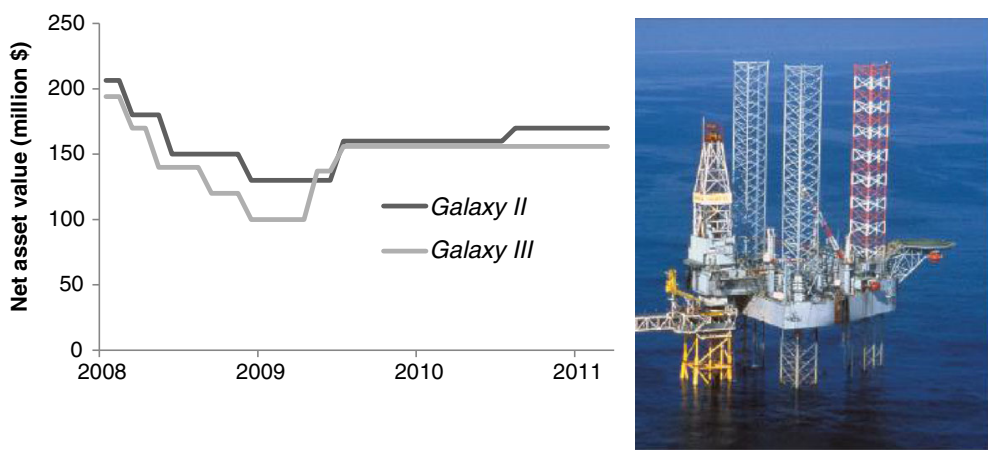

Fig. 15 NAV of the Galaxy II and Galaxy III jackups, 2008-2011, and the Galaxy II rig. Source: Jefferies (2008-2012), Drilling Contractor

When regional dayrates or utilization are depressed, NAV will generally decline, and conversely, when market conditions improve, NAV will increase.

\section{References}

Abrams JB (2010) Quantitative business valuation. Wiley, New York

Anderson JD, Aron A, Hoh S (2011) Transocean. J.P. Morgan, New York, NY

Antill N, Arnott R (2000) Valuing oil and gas companies. Woodlands Publishing Ltd, London, UK

Carter SM, Ghiselin RG (2003) Bringing efficiency to the offshore rig contracting business. Paper presented at the SPE/IADC Drilling Conference, 19-21 February, Amsterdam. SPE/IADC 79894.

Corts KS (2008) Stacking the deck; idling and reactivation of capacity in offshore drilling. J Econ Manag 17(2):271-294

DeLuca M (2001) To build or not to build. OilOnline, 30 April. Available from http://www.oilonline.com

Denning L (2012) Few home comforts for Europe's oil majors. Wall Street Journal, 5 October, C 10.

Glickman S (2006) Transocean. In: Standard and poor's 500 guide. McGraw Hill, New York, NY.

Grosbard A (2002) The Treadwell wharf in the Summerland, California oil field: the first sea wells in petroleum exploration. Oil Industry History 3(1):1-18

Halkyard J (2005) Floating offshore platform design. In: Chakrabarti S (ed) Handbook of offshore engineering. Elsevier B.V, Amsterdam, pp 419-661

Hartley P, Medlock KB (2008) A model of the operation and development of a national oil company. Energy Econ 30:2459-2485

International Valuation Standard (2005) 7th Edition. International Valuation Standard Committee, Washington, D.C.

Jablonowski CJ, Kleit AN (2011) Transaction costs and risk preferences: modeling governance in offshore drilling. Eng Econ 56(1):28-58

Jefferies and Company, Inc. (Jefferies). 2008-2012. Offshore Drilling Monthly. Jefferies and Company, Houston, TX

Johnson A, Fisk MC (2013) Transocean pleads guilty to violating Clean Water Act. Bloomberg. 14 February 2013. Available from http://www.bloomberg.com.

Kaiser MJ (2013) Oil and gas company valuation, reserves, and production. J Sustainable Energy Eng 2(1):1-39

Kaiser MJ, Snyder BF (2012) New model offers tool for analyzing rig day rates. Empirical relations characterize rig day rates. Offshore $72(9)$ : 40-42; 72(10): 54-58

Kaiser MJ, Snyder BF (2013) Capital investment and operational decision making in the offshore contract drilling industry: a case study. Eng Econ 58(1):35-58

Lawrence SD, Gabrielsen G (1989) Forecast and review: Offshore rig activity. Paper presented at the SPE/ IADC Drilling Conference, 28 February-3 March, New Orleans, LA. SPE/IADC 18644.

Lee Y, Garza-Gomez X (2012) Total cost of the 2010 deepwater horizon oil spill reflected in US stock market. J Account Financ 12(1):73-83

Lee J, Jablonowski CJ (2010) Measuring the price impact of concentration in the drilling rig market. Energy Sources, Part B 5:390-399 
Mascarenhas B (1989) Domains of state-owned, privately held and publicly traded firms in international competition. Adm Sci Q 34:582-597

McGuire TR, Gardner A (2003) Contract drillers and causal histories along the Gulf of Mexico. Hum Organ 62(3):218-228

Moomjian CA (2012) Drilling contractual historical development and future trends post-Macondo: reflections on a 35 year industry career. Paper presented at IADS/SPE Drilling Conference and Exhibition, 6-8 March, San Diego, CA. SPE 151442.

Moomjian CA (1999) Contractual insurance and risk assurance in the offshore drilling industry. Drilling Contractor January-February: 19-21

Osmundsen P, Sorenes T, Toft A (2008) Drilling contracts and incentives. Energy Policy 36(8):3138-3144

Pinto JE, Henry E, Robinson TR, Stowe JD (2010) Equity asset valuation. John Wiley and Sons, Hoboken, NJ

Rankin D (1981) The economics of the offshore contract drilling industry: implications for the operator. SPE Annual Technical Conference and Exhibition, 4-7 October, San Antonio, Texas. SPE 10329.

RigLogix (2011) RigLogix: upstream intelligence system. Available from www.riglogix.com.

Serbutoviez S (2012) Offshore hydrocarbons. Panorama, IFP Energies Nouvelles

Shrieves RE, Wachowicz JM (2001) Free cash flow, economic value added and net present value: a reconciliation of variations of discounted cash-flow valuation. Eng Econ 46(1):33-52

Sider A (2012) Transocean sells rigs, discusses deepwater. Wall Street Journal, 11 September, B4.

Slorer O, Loureiro P, Levi I, Swomley B (2011) Global oil services, drilling and equipment. Morgan Stanley, New York, NY

Speer P, Wood S, Coleman T, Austin K, Orman A, Messina FJ, French G, Congdon W (2009) Global oilfield services rating methodology. Moody's Global Corporate Finance, New York, NY

Thurm S (2012) Buyers beware: the goodwill games. Wall Street Journal, 14 August, B2.

Vazquez J, Michel R, Alford J, Quah M, Foo KS (2005) Jackup units: a technical primer for the offshore industry professional. Available from http://www.bbengr.com/jack_up_primer.pdf. 